$1-1-1943$

\title{
Epistle to the farm : The report of the director, West Virginia Agricultural Experiment Station, Morgantown for the biennium 1940 to 1942
}

C. R. Orton

Follow this and additional works at: https://researchrepository.wvu.edu/ wv_agricultural_and_forestry_experiment_station_bulletins

\section{Digital Commons Citation}

Orton, C. R., "Epistle to the farm : The report of the director, West Virginia Agricultural Experiment Station, Morgantown for the biennium 1940 to 1942" (1943). West Virginia Agricultural and Forestry Experiment Station Bulletins. 307.

https://researchrepository.wvu.edu/wv_agricultural_and_forestry_experiment_station_bulletins/308 @ WVU. It has been accepted for inclusion in West Virginia Agricultural and Forestry Experiment Station Bulletins by an authorized administrator of The Research Repository @ WVU. For more information, please contact ian.harmon@mail.wvu.edu. 



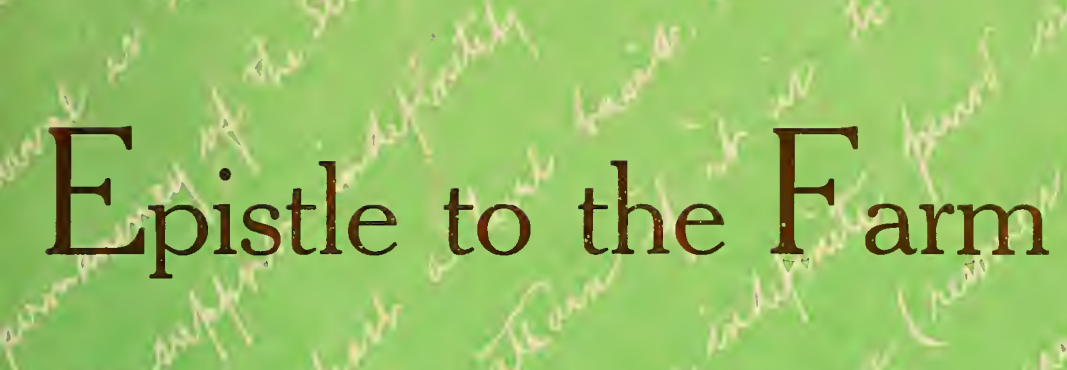

$$
\text { By C. R. Orton }
$$

Epistle to the Farm 
The classification of resources as indicated on the covers of this report is unique in the sense that it depicts them in chronological order of development.

A. NATURAL RESOURCES-Those which were provided by nature.

1. Primary Resources - Those which were created before life existed.

2. Secondary Resources-The appearance of living organisms; plants first because animals have to live upon plant life. Man stands at top of animal lingdom.

3. Tertiary Resources - Formed as a result of the interrelations between the primary (inorganic) and the secondary (organic) resources. Of these only the soil is renewable at the hand of man.

B. ARTIFICIAL RESOURCES-These are compietely dependent upon man's ability to conserve and use the natural resources. Remove any one of the primary or secondary resources and mankind leould perish. 


\section{A FEW OF THE CHAPTERS IN THIS EPISTLE}

See Page

More blades of grass $\ldots$

Hybrid corn for West Virginia

For bigger crops, keep up soil fertility $\ldots$

How soil behaves when wet...................................................... 13

What rootstock combinations for apple?

Keep the bearing orchard in sod!

Sequoia potato shows promise

Green manures sustain vegetable crop yields

How assure maximum economical beef production? _................... 20

Rabies in sheep

What about legume-grass and cereal silages?

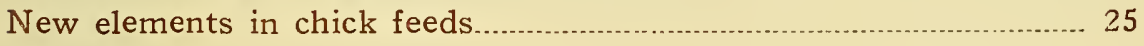

The avian leukosis complex......... 27

Foster mother of the human race............... 29

Simplified rations for dairy cattle

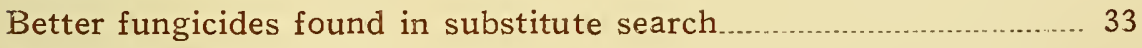

A promising rust-resistant cedar

Potato wilt of unknown cause

Codling-moth control

How well do university students eat?

How capture a vitamin?

What shall we do with our delinquent lands?

Good pastures, economic welfare go together................................. 44

The future of fire insurance mutuals..................... 46

How manage private woodlands profitably? ……......................... 48

Black walnut and apple trees do not agree..................................... 49

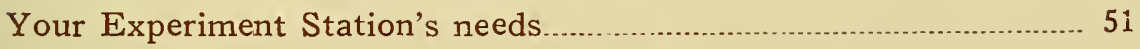

Publications of the biennium 1940-1942 

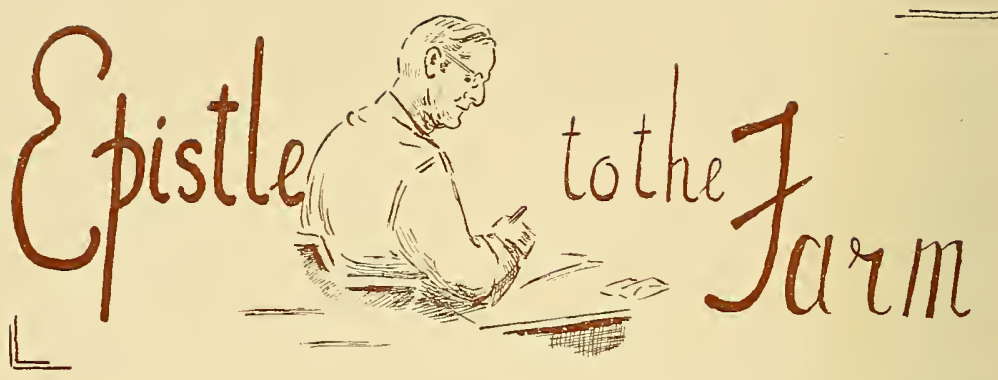

January 1, 1943.

To the West Virginia Farmer:

This year I am writing you a wartime epistle.

Total War changes our mode of life, our ways of distribution, our methods of production.

It is no different in the field of Agriculture. Here, all production has to be geared to the War effort.

We are acutely aware of this in our farm research program, and our outlines of projects have long ago been adjusted to meet the situation. In this process the Experiment Station has taken its place along with the Agricultural Extension Division in shifting the emphasis to the more immediate requirements of War.

These adjustments, naturally, cannot be made overnight. Long-time projects must be completed if their investment in time and money is not to be cancelled by suspension. That is why you will find a number of our old projects still running, but many new ones bearing directly on problems resulting from the War have been initiated.

In agricultural production during wartime the Experiment Station has to lead the way with recommendations based on soundly planned research. And once the War is concluded, the Station again must be prepared to give counsel for entirely different situations. Hence the need for continuous, long-time planning and experimentation in stock and crop production, in insect and disease control, and in the problems of distribution which long have beset the farming industry.

Sincerely yours,

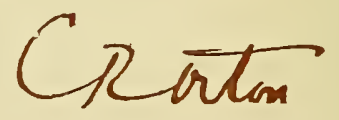




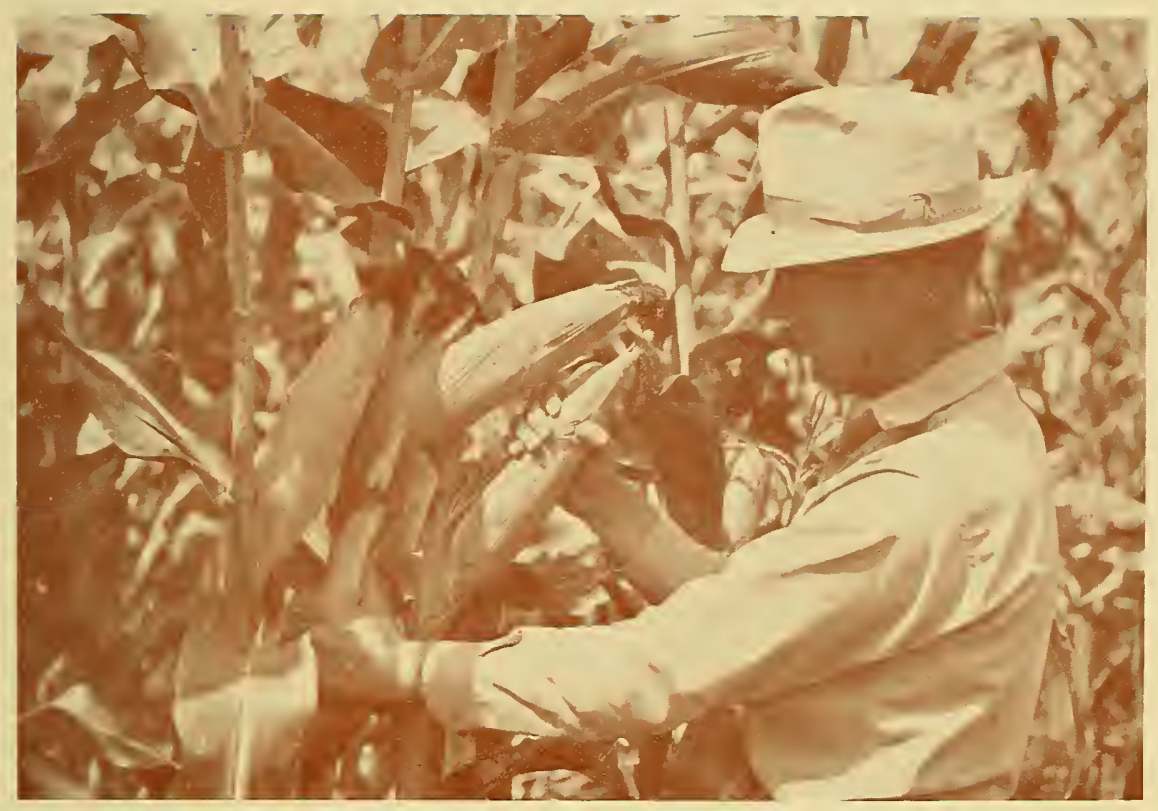

\section{Farm Crops and Soils*}

\section{More Blades of Grass}

It is human nature to let well enough alone. If the pasture is green rear after year and supports the livestock in seascon, that's that. Why fertilize it?

That is an easy assuruption to make. But rears of research at the West Virginia Agricultural Experiment Station prove the fallacy of this kind of reasoning. Too long have West Virginia pastures suffered from hunger. Like any other crop, they need fertilizer. Need it at fairly regular intervals (as the years go). The desirable grasses must have it. Otherwise the weeds take over. Wheu that hapreas, the stock suffers too. Pastures ar'e limited in area, and the steers can 't find greener fields elsewhere.

For many years we have been comparing fertilized pasture plots with unfertilized plots. Topdressings of lime and superphosphate have proved to be the best treatment for keeping up and even increasing the fertility of the pasture soil.

\footnotetext{
* The material in this Epistle was compiled by the Editor.
} 
That is a fortunate thing for the farmer. You know that nitrogen is on the war-vital list, so can't be had for field treatment for the duration. But the supply of lime and superphosphate is plentiful, and West Tirginia pastures could profit a great deal if they were plastered with these two ingredients. Nore and better stock per acre would be the result.

Now, a pasture doesn't need to be treated evory jear. And again, once in a lifetime is not enough. Our research workers--G. G. Pohlman, F. W. Schaller, H. O. Henderson, R. A. Ackerman, and E. A. Jivesayhave found that lime applications last about ten years, and superphoswhate around four years. At the end of those periods, the land reeds to be replenished.

Fertilizing pasture land has been found, over an eight-year period, to increase the yield of body-building grasses to a remarkable extent. In a complete fertilizer treatment (including lime), the number of pasture days and the pounds of gain per animal have more than doubled over those plots where there was no treatment.

Many of our permanent pastures contain very few desirable plant species. Topdressings of lime and superphosphate will improve such pastures only very slowly. These pastures need seed in addition to lime and fertilizer. Repeated tests have shown that scattering seed on old pasture sod is a waste of time and money. A study is now under way to find a practical method for reseeding poor hillside pastures. We are also investigating different kinds of grasses and legumes in order to insure quick establishment, high productivity, and longevity of the stand.

Contour furrows have been under observation for several years. In cooperation with the Soil Conservation Service, we studied what happened to the water caught in the furrows. It moved downward as readily as the soil would permit, but movement laterally was very slow and not enough to affect the vegetation above or below the furrows and the berm. We also studied the kind and amount of regetation in the furrowed areas. The regetation was best in the bottom of the furrow, and poorest on the ridge or berm. All in all, the area affected by the furrow produced no more vegetation than the area not affeeted. This was as expected, since the water retained in the furrows was not available to the vegetation.

\section{Improving Pasture Grasses and Legumes}

In 1940 we started a new piece of research with pastures - one that should go far in rejuvenating West Virginia's most important farm 
crop. Our agronomists - F. J. Wellhausen and R. O. Weibel - went to a large number of pastures in all parts of the state and lifted some 1400 plugs of sod, brought them to Morgantown, broke them up into individual plants of bluegrass and white clover, and set these out, $3 \mathrm{r} / 2$ feet apart, in a pasture nursery. A large number of plants started from seed collected from varions pastures were also transplanted to this nursery. Here the behavior of the individual plants is being compared from the standpoint of general vigor, disease and dronght resistance, heat tolerance, and many other characters. The best ones will be increased for more detailed studies. Eventually we hope to have seed uf some good ones available for farm use.

Preliminary study of the different plants of bluegrass obtained from the various pastures indicates that plants from poor pastures that is, pastures of low fertility, consisting mostly of unpalatable species of grasses, with some bluegrass scattered about - on the average have less ability to yield and less disease resistance than those obtained from pastures with a good, rigorous bluegrass sod of long standing. This inay mean that the practice of fertilizing a pasture and letting the bluegrass spread from the scattered types present here and there is all wrong. Up until the time seed of new improved strains becomes dvailable, it may be better to seed with seed collected from a good bluegrass sod of long standing, rather than letting the bluegrass sod thicken from the inferior plants that are scattered about in a poor pasture.

\section{Hybrid Corn for West Virginia}

Hybrid corn is proving its worth many times over. Ask the farmer who has grown this type alongside the usual open-pollinated varieties.

After a prolonged dry spell in Hardy County, on the South Fork of the South Branch, in 1941, a grower reported an excellent stand of hybrid corn, resistant to drought, with tassels dropping their pollen raturally, and kernels "shooting" in a full-grown ear. In contrast, open-pollinated corn on the same farm showed every indication of drought, with tops "fired," leaves seared, and ears undeveloped.

In that same dry summer of 1941 a Wayne County farmer reported great contrast between hybrid corn and open-pollinated corn in the matter of resistance to lodging. MIuch of his field was badly blown down in a high wind. But in the hybrid patch, the stiff stalks and the strong root system saved that part of his crop from wind damage.

Research at West Virginia University and in other states has made this possible. And there are other advantages. E. J. Wellhausen and J. L. Cartledge, our experimenters, tell me that growers realize from 
20 to 25 percent greater yield from adapted hybrid corn. In fact, most of the farmers in the cormbelt by now are growing this type and will lever go back to their standard rarieties. Theil yields are at least onefifth better, and they have found that the hybrids will not blow down as readily. Some of these hybrids are even more resistant to diseases, insect attack, or adverse weather conditions.

With the help of the Extension Division, the Experiment Station has sent out to W'est Tirginia farmers, for extensive field trials this past year (1942). 25 bushels of seed of each of two hybrids developed in our corn-breeding program. These two are excellent yielders and are well adapted to regions with elevations of 500 to 1000 feet in this state. 'i'wo other hybrids developed by our corn breeders have given outstanding performance in regions with higher altitudes or the shorter-seasoned areas of the state such as are found throughout Preston, Randolph, and Pocahontas Counties. About six bushels of seed of one of these hybrids is available for 1943 and will be sent to those farmers wanting to try it. Nore such stock will become available to growers as our studies lead the way.

Sweet-corn hybrids are also being developed. Seed of a number of sweet-corn hybrids showing superior quality, yield, and disease resistance will be increased in 1943 for more general observation on their adaptation and performance over the state. Both early and late hybrids are being developed so that the home gardener, by planting early in the spring a number of varieties maturing at successive dates throughout the season, can have sweet corn to eat all summer.

\section{What Soybeans, What Small Grains for West Virginia?}

Testing numerous varieties of cultivated crops has been one of the functions of the Agricultural Experiment Station erer since it was organized in 1888. In a state like West Tirginia, presenting wide variations in altitude and also considerable differences in latitude, one must cxpect extremes of climate and therefore of growing conditions - not to mention all the differences encountered in the many types of soil. All this means that a given variety of erop may not - and in all probability does not - thrive under all of the conditions to be found in the state. It means that we must have different rarieties for the same crop.

Well, what have we done in this direction in the Mountain State? Every year, for a half century, we have been carrying out extensive field trials with the major crops, always with the aim of finding the most profitable variety under West Virginia conditions. We have done this in representative regions of the state for oats, wheat, barler, and 
TWO STRIINS OF BLEEGRASS UNDER IDENTICAL CONDITIONS SHOWTNG

YARIKED

DIFFERENCE IN GROWTH

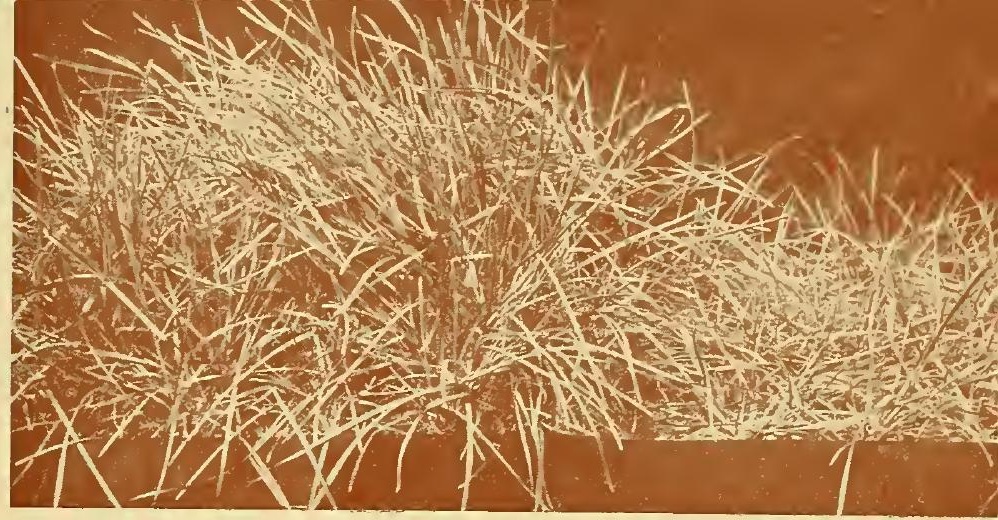

soybeans. Here is what R. O. Weibel and E. J. Wellhausen report this year:

The varieties of winter barley recommended include Scottish Pearl, Kentucky Nos. 1 and 2, and Tennessee Winter No. 52. Scottish Pearl is a consistently high vielder and seems adapted to all the state. Kentucky Nos. 1 and 2 are especially winter-hardy, and Tennessee Winter No. 52 seems to be especially adapted to Eastern Panhandle conditions. Winter barley should be seeded at the rate of two bushels per acre, not later than September 15 for lower altitudes of the northern one-third of the state, and not later than September 20 to 25 for the southern part of the state, depending on altitude. Winterkilling makes winter barley an unreliable erop in the higher altitudes of the northern third of the state.

Recommended varieties of winter wheat are Thorne, Fulhio, Trumbull, Leap's Prolific, and Nittany. Gopher and Patterson oats are on the list and so are Kingwa, Wilson, and Scioto soybeans. There is not enough information on winter oats to make definite recommendations. However, they are not as winter-hardy as winter barler, and they must be seeded at least as early as the dates indicated for barley. Two bushels per acre is the recommended rate to seed. Trials of winter oats so far indicate that the variety Lee from Tirginia is the most winter-hardy and has good straw. It is susceptible to smut. The varieties Tennex and Fulwin from Tennessee are not as winter-hardy or as lodge-resistant as Lee. With no winterkilling or lodging they will outyield Lee.

\section{Toward a Tastier Sweet Clover}

Coumarin is that distasteful element in sweet clover that makes cows turn up their noses. Some years ago one of our chemists, I. J. Duncan, developed a short method of isolating this substance chemically. Since then we have been making many breeding tests in an attempt to 
develop a strain of the plant that has no noticeable amounts of this bitter stuff. At the same time we must strive for disease resistance, leafiness, fine stems, vigor, and a high tolerance of acidity. E. J. Wellhausen is busy on this piece of research which, like any project involving breeding, takes years to finish.

So far, the breeding work has been concerned with the development of lines breeding true for coumarin content, leafiness, fine stems, and disease resistance by inbreeding. One hundred seren inbred lines are now under observation. Some of thcse are leafy, bushy, fine-stemmed types which are breeding relatively true. Coumarin content of these lines ranges from a low of 0.31 percent to a high of 1.20 percent on a ciry-weight basis.

All of the inbred lines have lost rigor as a result of inbreeding. The problem now is to combine the best inbred lines into a rigorons srnthetic variety with such desirable characters as leafiness, low coumarin content, and disease resistance.

\section{Breeding Tobacco for Disease Resistance}

For some years we have been testing yield and quality of 14 improved strains of tobacco, in soil infested with root rot. These included six strains developed locally, seven improved strains from Kentucky, and Kelley, the variety that used to be a good yielder but does not stand up under root rot attack.

E. J. Wellhausen, T. C. McIlvaine, and J. G. Leach, in experiments carried on at Lakin in cooperation with the federal Division of Tobacco Investigations, report that not one of the locally developed strains is any better in yield or quality than Kentucky No. 16, when grown in irfested soil. In fact, Kentucky Burley No. 48 yielded $\$ 419$ per acre, with its nearest West Virginia challenger, West Virginia A 100, running $\$ 60$ under that figure.

The researchers tell me that the same varieties might be recommended to West Virginia growers as are now recommended in Kentucky.

\section{Breeding Watermelon for Wilt Resistance}

Since Fusarium wilt became established in West Tirginia, much of the land suitable for watermelon culture has become so thoroughly infested that it has made the growth of melons hazardous and umprofitable. If we can produce suitable varieties that are also wilt-resistant, the industry could be restored, and West Virginia melon grower's would stand to profit once more.

Our agronomists, horticulturists, and plant disease workers have been working at this problem for several years. All available varieties 
from other states have been tested. It was found that none of these varieties was resistant to the strain of wilt prevalent along the Ohio Iiver bottoms, although many of them were highly resistant to wilt in the respective states in which they were dereloped. It seems then that the development of wilt-resistant varieties is largely a local problem. The problem is tough, for resistance must be combined with high vields and good quality.

So far, in the course of our breeding program two high'y wiltresistant strains of watermelons have been developed. One of these was dereloped from a eross between a Russian melon and Early Fordhook. The other was dereloped from Stone Mountain through selection on wilt-infested soil. The resistant selection from Stone Mountain is ihe better of the two, but its quality and yielding ability still need to be improved.

E. J. Welihausen and J. G. Leach are trying to combine the resisttance of this Stone Miountain with quality and yield by following a method of breeding that has worked so well with hybrid corn. The resistant Stone liountain selection was crossed on a large number of good quality melons. Three of these crosses, namely, resistant Stone Mountain X Improved Clover Belle. resistant Stone Mountain I Hawks. bury, and resistant Stone Mountain X Iowa Belle, have shown considerable promise. They are now investigating the possibility of putting these into production in much the same fashion as hybrid corn.

\section{For Bigger Crops, Keep up Soil Fertility}

One of our biggest problems is the production of crops for feed so that we can supply our own people and our allies with sufficient food. At the same time re must not forget that we need to maintain our soil fertility in order to keep up our crop production. Our agronomists. T. C. McIlvaine and G. G. Pohlman, have been working on this problem for a number of years and have discorered certain ways in which every farmer can maintain his soil fertility and production.

(1) The rotation used will greatly influence the crop. We have used a good many different rotations and treatments They all show that short rotations (2 years or less) are not as good as longer rotations (3 years or more); that rotations having clover or alfalfa sods whichi are plowed under give better results than those which do not have these legumes; that manure and lime are necessary for maintaining high yields.

(2) If farmers must use short rotations, leguminous corel crops will help keep up the rield. Again, since 1937 a sweet-clorer corer crop 
seeded in wheat in a corn-wheat rotation inereased the com yields from 17 bushels to 55 bushels per acre. These plots had the same rotation and fertilizer, but one has never had a cover crop, while the other has had cover crops since 1924.

(3) Manure increased the yields in all rotations tested. Results for two comparable rotations are given in the following table:

\section{Corn Yields, 1937-1941, as Affected by Manure}

\begin{tabular}{c|c|c|c}
\hline ROTATION & $\begin{array}{c}\text { PHOSPHATE } \\
\text { ONLY }\end{array}$ & $\begin{array}{c}\text { MANURE PLUS } \\
\text { PHOSPHATE }\end{array}$ & $\begin{array}{c}\text { COMPLETE FERTILIZER } \\
250 \text { 1bs. } 4-10-6\end{array}$ \\
\hline $\begin{array}{c}\text { Corn, soybeans } \\
\begin{array}{c}\text { Corn, small grain, } \\
\text { clover-timothy }\end{array}\end{array}$ & $25.6 \mathrm{bu}$. & $55.7 \mathrm{bu}$. & $45.7 \mathrm{bu.}$ \\
\hline $6.6 \mathrm{bu}$. & $80.1 \mathrm{bu.}$ & $87.6 \mathrm{bu.}$ \\
\hline
\end{tabular}

In these rotations the manure was applied to the land before plowing for corn. In the two-year rotation we got higher yields of corn from manure than from complete fertilizer. Yields in the 3-year rotation were relatively high, partly because all of the land had been manured for 12 years before 1937 . The longer rotation containing clover and timothy sod also helped maintain yields. In spite of this, manure increased the yield. . . Irith present shortage of nitrogen it is extremely important to conserve the manure and use it where it will do the most good.

(4) Liming acid soils likerise increased the rields of crops in practically all rotations. Corn vields have been increased as much as 36 bushels per acre by the application of lime, with an average of 17.5 bushels for nine rotations. Wheat yields have averaged 2.2 bushels higher on limed plots, barley yields are 6.8 bushels higher, and hay yields 1300 lbs. more on limed than on unlimed plots. Even Korean lespedeza, which is relatively acid-tolerant, has yielded 2310 pounds per acre on limed land as compared to 1320 pounds per acre on unlimed land.

(5) Fertilizer trials have shown that our soils respond to nitrogen, phosphorus. and potash fertilizers. The response to the rarious elements depends upon the cropping system and upon soil management. Rotations with manture added have given little response to nitrogen fertilizers. Our experimenters got 75 bushels of corn, 34 bushels of barley, and 1.7 tons of elover and timothy hay as average yields since 1937 on plots which had only manure and phosphate. If you don't have enough manure - and most farmers don't - turning under legumes or legume sods will stupply much of the nitrogen and organic matter, 
and you will be able to produce good vields by adding phosphate and potash fertilizer. Plowing under sweet clover in a corn-wheat rotation has given as good yields of both coln and wheat as applying 100 pounds of sulphate of ammonia.

Potash fertilizers have given particularly good results on the soils which have been limed.

Nitrogen fertilizer's can't be entirely eliminated. but we must renember this - the lind of cropping system has as much effect on your yields as the kind and amount of fertilizer you use. By doing a good job of organizing your rotation, using lime, manure, and legumes, and keeping soil erosion at a minimum, you can produce good crops and maintain soil fertility reasonably well. eren with the limited nitrogen supply now available.

\section{How Much Lime for Grain and Hay?}

Since 1929 we have been testing various crops to see how much lime was needed in the soil for their best growth. The crops tested have been corn. wheat. barley, rye, sorghum, Sudan grass. millet, tobacco. sweet clover, alfalfa, red clover, alsike clover, lespedeza, compeas, and soybeans. The rields have generally increased as the amount of lime acded was increased, but there were wide differences with different crops. Alfalfa and sweet clover made practically no growth when the soil was more acid than pH 5.5 (moderately acid soil), wheleas rye made 90 percent maximum growth at plI 4.5 (very strongly acid soil). Of the other crops tested at $\mathrm{pH} 4.5$. rields were less than 50 percent of maximum. The data on this experiment are being prepared for publication by T. C. McIlvaine and G. G. Pohlman.

\section{Lime and Fertilizer Needed for Alfalfa}

It is entilely possible to grow alfalfa on well-drained soils of the state, and do it successfully, if the proper applications of lime and fertilizer are made.

But the soil for this plant must be neutral. That takes lime if it is sour. And alfalfa, being high in phosphorus content, must be able to get that element from the soil. That means fertilizing with superphosphate. Nitrogen is not the limiting factor in alfalfa growing. This plant, being a legume, manufactures its own.

G. G. Pohlman and W. II. Broadfoot have found over a period of years that with an adequate supply of lime. heary fertilization with superphosphate and muriate of potash is generally economical. 13y analyzing many samples of the alfalfa produced, they found that the phosphorus content can be increased materially when the soil is treated 
with the right fertilizer. It's the old cycle - better soil, better crops, better livestock, richer food for man.

\section{How Avoid Phosphate Knots in Soil?}

When phosphate fertilizers are mixed with soils, the phosphorus is quickly changed to compounds which do not easily dissolve in water. Usually, if the soil has been limed recently, plant roots can get back much of this phosphate fertilizer by dissolving these compounds. If the soil is acid, however, the clay ties the phosphate fertilizer into a phosphate knot or compound which plant roots cannot easily untie or release. As a result the plants starve for phosphorus. We call this phosphate knot, fixed phosphorus. Since the knot is tied quickly and nore or less for good, a farmer can easily lose a large part of the money he invested in phosphate fertilizers when applied broadcast to acid soils. Now with most soils, phosphate fixation or the phosphate knot can be largely aroided by liming. However, it has been found on soils in West Virginia that liming doesn't reduce phosphate fixation as much as expected. E. H. Tyner and J. R. Webb are working with some of these soils. Just how prevalent these soils are and what can be done to reduce their phosphate fixing power they are not in position to say. In the meantime they advise applying phosphate fertilizers broadcast only after the land has been limed - never before; or using fertilizer attachments that put the phosphate in bands near the seed.

\section{Vegetative Cover for Eroded Soils}

The Experiment Station is looking for ways to stop erosion and to reclaim soils which have been badly eroded.

At the Reymann Memorial Farm in Hardy County we planted grasses, legumes, and trees on badly eroded soils to determine which would make the best cover and which would improve the soil most rapidly. Thus far sweet clover, tall oat grass, and redtop have made the best cover and most growth on the grass plots. Of the trees used. Virginia pine, red pine, black locust, and hybrid poplar have shown good survival and have made excellent growth. An application of fer. tilizer doubled the growth of locust trees the first year, but it had little effect on the growth of American red pine.

A badly denuded area in Harrison County was limed, fertilized, and seeded in 1942 to a mixture of native and introduced grasses and several legumes. The mixture inchded weeping love grass, Lehmans love grass, partridge pea, two species of lespedeza, hop clover, wild rye, birdsfoot trefoil, timothy, orchard grass, redtop, and zigzag clover. After 
THIS SOIL SLIP

FOLIOWED THREE

DAIS OF RAIN,

WHEN $\triangle B O U T 4$

INCHES FEII.

seeding, the area was mulched with straw and chaff which carried a considerable number of seeds of native grasses and weeds. A good corer was obtained consisting of the species planted, as well as weeds and native grasses from the mulching material. From early observations zigzag clover, birdsfoot trefoil, and Lehmans love grass appeared especially promising. Orchard grass, timothy, Canada wild rye, and redtop made satisfactory growth. In addition "deer tongue", which was brought in with the mulch, was making good growth. It is still too early to draw definite conclusions, but present evidence indicates that, with adequate amounts of lime and fertilizer, a good vegetative cover can be secured over this area.

\section{How Soil Behaves When Wet}

In our Mountain State certain conditions of bedrock, soil, slope, and precipitation combine to shove patches of hillside sod and soil out of place, with resulting damage ranging from a slight roughening of the land surface to complete removal of soil; movement and breaking of fences and buildings; and burial, hearing, and displacement of roads and highways. These "soil slips" are most abundant in the northwestern third of the state.

This area of slip prevalence is much like other parts of the state as regards slope of land and the occurrence of prolonged rains, but differ's notably as to bedrock and subsoil. Bedrock lere consists of nearly level, relatively thin layers of soft, easily disintegrated shales interbedded with sandstone, clay, coal, and limestone. The slow transformation of rock to subsoil has retained much of the original layering, although solution, creep, and slump have thinned the layers and tilted them to slope with the land surface. 
Each subsoil layer differs from its neighbors. Some retain considerable strength when water-soaked; others become very soft, may even llow while in this condition. Many different arrangements of layers exist; some yield stable slopes, others produce slips sooner or later. To avoid or reduce damage from soil slips we must first become familiar with the materials and their arrangement in the soil and subsoil.

-Detailed pictures of subsurface conditions in and adjacent to slips have been constructed from examination and analysis of systematically located soil cores. (Soil cores are taken to depths of 15 feet much as cheese or butter samples are obtained.) The holes produced by coring are used to determine the position of free water in the subsoil. From these pictures we learn where unstable conditions exist or are likely to develop, and why. The information and methods will be useful in recovering slip-damaged fields, in locating diversion ditches and terraces, and in the stabilization of road cuts and subgrades. Incidentally, some of the findings in regard to the deeper parts of the subsoil may lead to better adaptation of some hillside crops to particular locatious.

In this work, directed by S. I. Galpin. the Station has had the cooperation of the State Road Commission.

\section{Mine Waste and Stock Water}

Many pasture water supplies have been ruined (especially in the Monongahela watershed) incidentally to the removal of coal. Water issuing from both active and abandoned mines carries too much in the way of soluble sulphates and free sulphuric acid to be palatable to stock.

We are investigating the possibilities for some simple, cheap chemical treatment that will make such water usable. The benefits of a practical treatment, if found, are too obvious to need mention.

Also planned under this project are trials to obtain water for stock from subsoil seepages by means of hillside trenches and also by walls sunk in the ground to intercept and store water below the surface.

Work on this project is also directed by S. L. Galpin. 


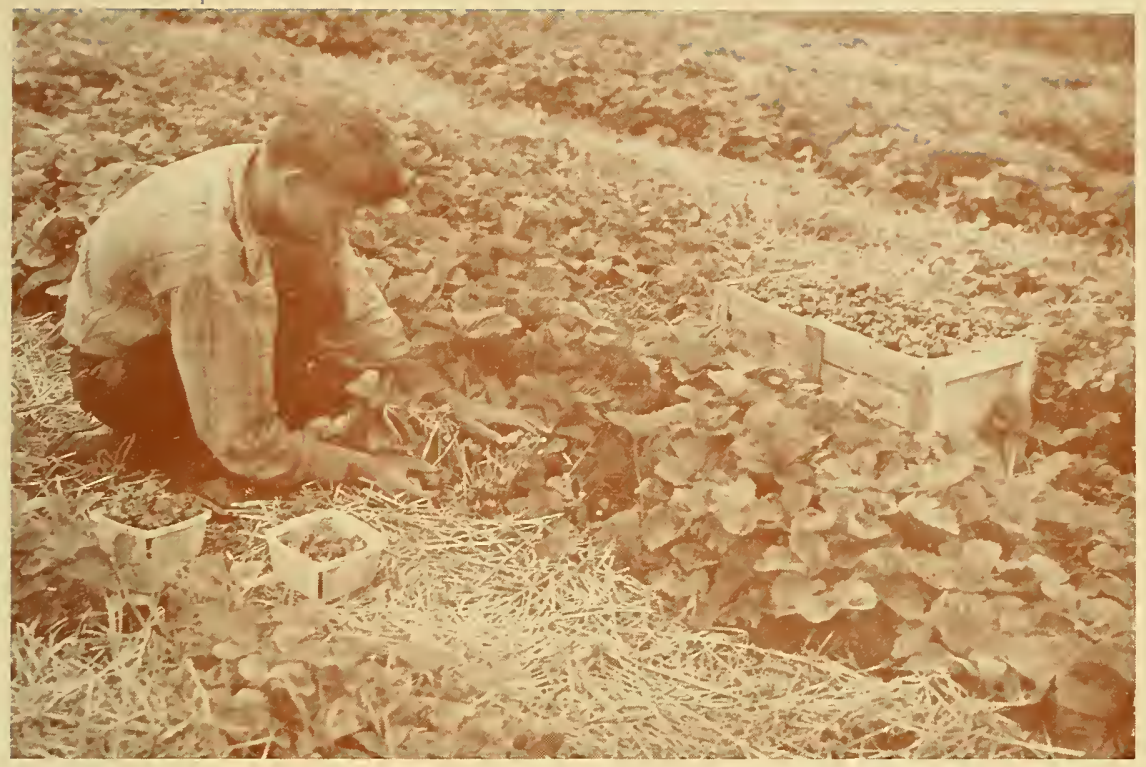

\section{Fruits and Vegetables}

\section{What Rootstock Combinations for Apple?}

There are some combinations of seedling or clonal rootstocks and scion varieties which should not be used in commercial apple orchards; there are still other combinations of considerable promise, such as clonal rootstock 316 and Jonathan seedlings, both of which produce large trees. Then there are some combinations which have resulted in trees of less than full size and which hare produced well and are easy for the growers to manage.

We have made this information available to commercial nurserymen as well as to all members of the Northeastern States Rootstock Conference. The latter is composed of those men working with rootstocks in the northeastern experiment stations and in the Bureau of Plant Industry, United States Department of Agriculture.

R. H. Sudds, who is in charge of this project in cooperation with E. A. Siegler of the federal Bureau of Plant Industry, is experimenting with numerous combinations. They hope to find some which will induce a somewhat smaller mature apple tree, especially on our heavier limestone soils. This ideal tree, long sought by growers, should also bear earlier besides reaching maturity sooner. 


\section{What Substitutes for Commercial Nitrogen for Trees?}

We are conducting an experiment on the effeet of cultural practices and orehard soil management on soil moisture and availability of plant nutrients to fruit trees. R. H. Sudds is in charge. This study is too new for results of any sort. But I deem it well to point out that it promises to tell us much about the possibilities of replaeing commereial nitrogen (a eritieal element these days) with nitrogen derived from legumes and from organic mulches. This is a matter of great practical importanee to the fruit-growing industry, even in normal times.

\section{Keep the Bearing Orchard in Sod!}

Shall we eultivate the sod in our bearing eommercial apple orehards?

The answer seems to be No! Researeh by R. H. Sudds and G. M. lirowning finds the evidence all against sueh practice. They have experimented with representative soil types in commercial orchards in the Eastern Panhandle. Their results emphasize the importance of organic mulches or adequate plant cover to proteet the surface soil from the beating action of intense rain. Sueh rain brings some of the soil particles into suspension. In this stage they either are lost as run-off, or else they elog the surface pores. In either ease the loss of both soil and water is increased.

Orehards which have been in sod continuously have antomatically maintained conditions which would eneourage the rapid filtering of rain water down into the soil. Little water and little soil would be lost in this way.

Consider the eontrast under cultivation. It tends to deplete the fertility of the soil through loss of organic matter, and this action affeets unfavorably the soil's desirable physical properties. In this way it makes the orchard site more subjeet to losses of water and of soil. And it makes the trees more liable to injury by drouth.

So it's thumbs down on eultivation in the bearing apple orchard.

\section{Mulching and Spacing of Small Fruits is Beneficial}

Aceording to W. H. Childs, mulching is a help to red raspberries, at least in this state, where many of the sites for plantings of small fruits are somewhat sloping. Mulching with threshed straw or seed-free hay shows partieular promise as a means of holding down soil erosion. At the same time, it ups the yields..

In strawberry culture, we find that spaeing the plants is better than using a matted row - one-fourth to one-half better, in fact. Wheth- 
ex it pays may depend on how much time and work is involved. A rough method of spacing, we think, would be profitable.

\section{New Late Strawberry Variety is Worthy of Trial}

The Red Star strawberry variety, recently introduced by the U. S. Department of Agriculture, shows promise in limited trials of being an outstanding late berry. This is good news for those growers who hitherto have looked in vain for a good late variety.

\section{For Better Blueberry Pies}

There are sections of the Mountain State - the high altitudes of the Allegheny Front, for example - that are very well adapted to the growing of blueberries. In some places the woods are full of them. T'rouble is, because they are wild, most of them produce small fruits, and it takes forever to pick a peck of them. Still, each year finds thousands of pickers in the blueberry barrens.

We believe that, if a fain'-sized berry could be developed, the trade could take on proportions which would yield substantial profit to owners of such land. So, for several years, W. H. Duis (who left us in 1941), along with R. S. Marsh and W. H. Childs, experimented with native species and crossed them with several named varieties. Both high-bush and low-bush varieties were used.

One outstanding selection (Taccinium angustifolium) that was discovered in this experiment grew berries with a diameter of 16 millimeters and of superior quality. 'That's better than half an inch. This piece of work has not been completed. When it is, we think we can point to a potential source of profit-yielding blueberry varieties which will supplant the small fry so long in evidence.

\section{Sequoia Potato Shows Promise}

If bread is the staff of life, potatoes should rate a close second -. with their well-nigh universal popularity on America's dinner table.

But there are potatoes and potatoes. So what should the commercially minded farmer grow? Much depends on the altitude of his land, and with altitude, the degree of freedom from disease.

K. C. Westover and J. G. Leach have taken selections from many crosses and their seedlings. Performance trials were made with these at altitudes of 600 to 2700 feet. Their results to date point to Sequoia, a recently introduced variety. It has yielded well in all trials in the niddle and higher altitudes and it gave better than average vields under "early potato" conditions. Sebago, Katahdin, and Chippewa vielded well but they were inconsistent. 
Sequoia is a potato of possible commereial promise, even if it is slightly oversize and its quality only ordinary. Properly graded, it will do. It is resistant to insects and it has vigor. It might do well as a home or subsistence-garden crop where ordinary methods of production prevail and where insect and disease control are generally inefficient.

\section{Green Manures Sustain Vegetable Crop Yields}

The continuous cropping of early cabbage and early tomatoes, followed by a rye \& vetch cover crop, has been used as a check treatment in a comparison of rotations of different lengths.

K. C. Westover reports that this check rotation, year after year, gave yields of cabbage equal to all other rotations tried, no matter how long the rotation or how it was made up. The same was true of early tomatoes, but it did not hold true for the entire season's yield. There the longer rotations, in some of which cuttings of timothy and red clover and alfalfa remained on the ground, gave greatest yields of tomatoes, especially when these were followed by a year's cover crop of rye \& retch and soybeans. For camning-crop or other late-crop purposes it appears that the longer rotations are best.

\section{Fertilize Asparagus Right After Harvest}

At the end of four years of trials. K. C. Westorer reports that a treatment of 6-8-12 fertilizer. 800 pounds to the acre, applied to asparagus after harrest, gave the highest yields the following season--375t pounds to the acre. Half as much potash did almost as well-3723 pounds of the crop on owe acre. More fertilizer than this failed to increase yields.

The important thing to remember is that in all trials, the highest yields came only when the fertilizer was applied immediately after hal'vest.

This experiment hasn't been finished, but results so far give some idea of what may be expected with this choice item of the dinner table. 


\section{Does It Pay to Harden Vegetable Plants?}

After sereral trials with numerous regetables. E. P. Brasher and K. C. Westover report these conclusions:

1. The prevailing practice of hardening regetable plants is not beneficial to all crops.

2. Eggplant and pepper do better with a slight hardening but are rnarkedly slowed down when overhardening is practiced.

3. Cabbage and head lettuce are benefited with the customary hardening, but their capacity to withstand cold depends on the temperature prevailing after transplanting. If low temperature continues, the plants become hardened and resist freezing. They apparently become tender again in warm weather. The rapid lowering of the temperature is often injurious.

\section{Use Topping Only as an Emergency Measure}

Ordinarily we grow certain crops and let Nature take her course. When we want certain effects we vary the conditions under which plants grow. Perhaps we are after greater volume of crop. Perhaps we want earlier maturity. The final ain is greater net returns from the crop.

K. C. Westover had this in mind when he started eertain experiments with the tomato. He sought to determine the effect of topping young plants, 10 days to two weeks before they should be set, on maturity, yield, and fruit set - for both early (Early Baltimore) and late varieties. He also wanted information on whether it is better to top rather than harden (Miarvelous), which reduces yields, as a means of holding young, tender plants during unfarorable weather eonditions at planting time. Results so far are as follows:

(1) Topping tended to reduce the early rields of unstaked plants of both varieties, but as the season adranced, there was no appreciable difference between topped and untopped plants.

(2) Considered in a general sense. the topping treatment appears to be a practical means of holding roung plants late in the planting season in an emergency, particularly when the entire crop is to be marketed. 


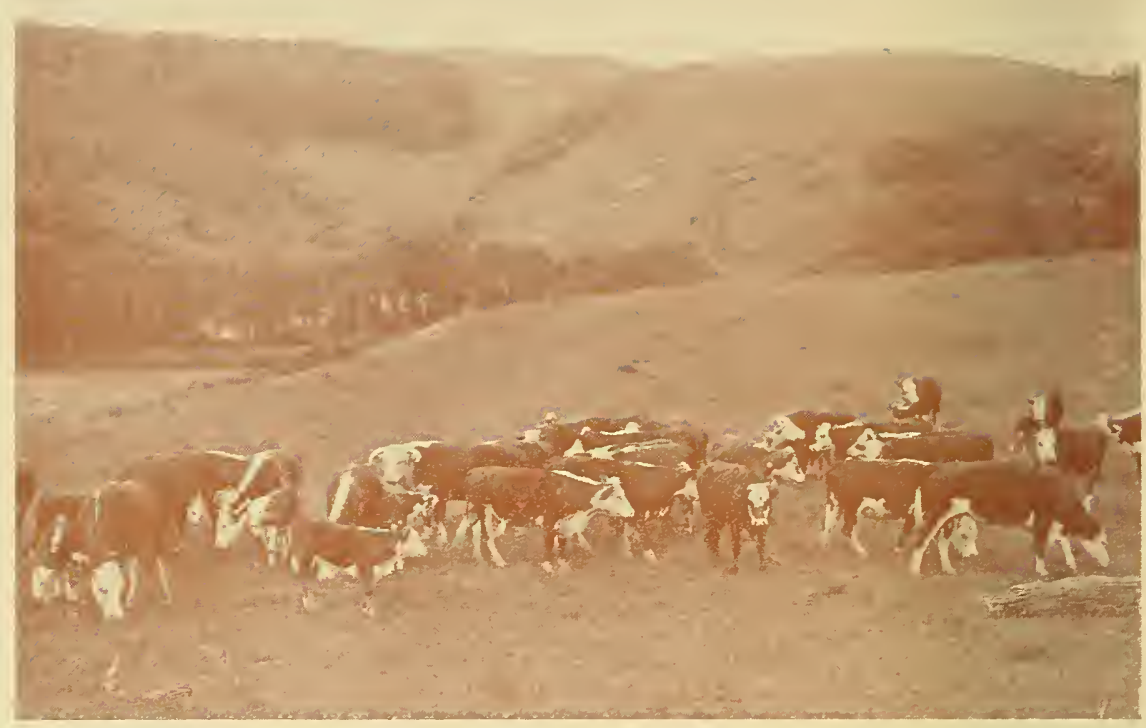

\section{Animal Husbandry}

\section{How Assure Maximum Economical Beef Production?}

Since 1930 C. T. Wilson of the Experiment Station and W. H. Black of the federal Bureau of Animal Husbandry have conducted a series of experiments with beef cattle at Lewisburg. Seventy high-grade Hereford cows, bred each year to registered Hereford bulls, have been maintained for the production of beef calves. The calves areraged around April 1 for date of birth and ran with their dams on pasture until about November 10, when they were weaned and started on feed. About December 1 , the calves were placed on winter rations that averaged approximately $13 \mathrm{I} / 2$ pounds of corn silage, $3 \mathrm{I} / 2$ pounds of coarsely ground shelled corn, one-half pound of cottonseed meal. and $t$ pounds of alfalfa or clover hay for the steers, and the same kinds and amounts for the heifers, except for the corn. The amount of corn for the heifers averaged approximately $23 / 4$ pounds daily.

The winter gains on the rations fed the calves reported herein averaged approximately 1 pound per day for the heifers and $1 / 2$ pounds for the steers.

At the end of the winter period during the rears 1940-41 and 1941-42, the steers were divided into 2 equal lots for summer feeding 
on pasture. One lot was fed an average daily ration of approximately S.5 pounds of coarse ground shelled corn on pasture, the other lut the same amount of a grain mixture composed of 8 parts corn and 1 part protein concentrate mixture cottonseed meal and linseed meal. half and half. Both lots of steers rere pastured together. The addition of the protein concentrate to replace part of the corn made no significant difference in the gain, final weight, carcass grade. dressed rield. or selling price of the live stecrs or dressed carcass.

The heifers rere divided into 2 equal and uniform lots. One group of heifers was fed in dry lot, the other on pasture. Both lots were fec! an average daily ration of approximately $T 1 / 2$ pounds of grain supplement. Clover or alfalfa hay was fed the dry-lot heifers in an amount that obtained the same gains, final weight, carcass grade and dressed rield as for the grass-fed heifers. It required approximately 10 pounds of hay daily to give the same results as the pasture results.

The heifers and steers were marketed between August 1 and 15 each year at an average weight of about 875 pounds for the steers and iT5 pounds for the heifers. The average weight of the heifers was Jower, partly because the top heifers were selected for herd replacement.

The summer gains made by both heifers and steers, approximately 2 pounds per day, the relatively small amount of grain fed, 650 to 800 pounds, the quality and degree of finish as measured by carcass grade, from middle of "good" to high "good", the ready acceptance of the dressed meat by the meat trade and by the consumer - all go to confirm our findings that a grain supplement, when fed as in these experiments, will enable the grower to market his young cattle satisfactorily and with profit, when he uses pasture and home-glown roughages to the utmost.

Lnder the plan used in these experiments, full values were obtained for the feeds used and for the steer and heifer calres.

A maximum of pasture and a minimum of tillable land area is required.

This procedure assures economy in production and maximum beef tomnage for the land area used, and a high-grade herd of cows is maintained by replacing the old and less desirable cows with selected heifers.

\section{A Good First-Cross Ewe for Mutton and Wool}

Here is a project which has been completed after 12 rears of painstaking research in the practical application of breeding principles. And we are able to make reliable recommendations for the guidance of the West Tirginia sheepman.

In 1930 C. T. Wilson, acting for the Experiment Station, and D. A. Spencer, for the federal Bureau of Animal Industry, began this experi- 
ment. They mated ewes of grade Hampshire type - a common type in many West Virginia flocks - to Corriedale rams. Wether lambs from these matings were slaughtered for carcass and meat studies, and the ewe lambs were kept for investigations of fleeces and breeding ewes. This scheme was repeated each year, and the ewe progeny was always riated back to Corriedale rams. In this way it was possible to get four straight generations of Corriedale-sired lambs.

Our best results were noted in the first cross. The ewe lambs in this cross grew into mature ewes fully equal to their dams in size and form, and the wether lambs were very satisfactory market lambs. The ewe lambs produced fleeces that averaged an inch longer in staple than that of their dams. And the fleece was just as dense, besides being somewhat finer and of better color. And on the basis of average clean yield, the daughters' fleece was fully one-fourth heavier than the fleece of their dams.

This fleece improvement was fully retained in second- and thirdgeneration crosses. But when it comes to the wether lambs, their weights and their gains to weaning age declined as the Corriedale blood increased.

The net result of this work is that farmers in West Virginia and in other Appalachian states can use Corriedale rams to produce satisfactory crossbred wethers for market and ewes with a superior length and grease weight. Such ewes may then be crossed with a Southdown, Shropshire, or Hampshire ram for the production of market lambs of top quality.

\section{How Early to Treat for Stomach Worms?}

The control of parasites is one of the important problems facing the sheep industry of West Virginia. Stomach worms, nodular worms, and the bankrupt group are the worst offenders.

The results so far obtained by J. H. Rietz and C. T. Wilson, with the use of a $1 / 2$ pereent copper sulphate solution, or a mixture of equal f arts of a $1 \frac{1}{2}$ percent copper sulphate and $1 \frac{1}{2}$ percent nicotine sulphate solutions, indicates that with early lambing. the lambs should not be treated before they are 10 to 12 weeks old.

Early lambing, combined with good feeding of both the ewes and the lambs (creep feeding), has produced satisfactory market lambs at an average age of $4 \frac{1}{2}$ months without treatment. The results indicate that all lambs should be treated when weaned (41/2 months old or 50 to 60 pounds in weight) and fed grain in feed yards or pens or on clean, fresh alfalfa or clover meadow pastures. 


\section{Rabies in Sheep}

On August 9, 1942, J. I. Rietz reports, four dogs were found attacking a flock of lambs belonging to the University. No lambs had been killed, but a number showed lacerations about the face and head. Two of the dogs were killed in the pasture, one was killed the following day, and one was captured in the aftemoon of the day of the attaek on the lambs. This dog was placed under confinement, was diagnosed as a "rabies suspect" the following day, and died August 13. Examination of the brain was positive for rabies.

From August 25 to September 30, out of a flock of 65 head, 21 lambs sickened and died of rabies as a result of the attack of the dogs.

Diagnosis of rabies in the lambs was made from brain examinations.

Whether mole than one of the dogs were in the incubative stage of rabies at the time of the attack on the lambs was not determined, but one of the dogs was definitely proved to be a case of rabies..

Among the lambs dead of rabies were ram lambs, contracted for at prices ranging from $\$ 35$ to $\$ 50 \mathrm{pel}^{\circ}$ head.

Besides the loss of the lambs, three employes of the farm were definitely exposed to the infected lambs and were required to submit to the anti-rabies vaccination.

\section{What About Legume-Grass and Cereal Silages?}

Silage from corn has been the accepted form ever since the idea of cnsiling a crop first took hold.

E. A. Livesay, B. H. Schneider, and A. H. VanLandingham have been comparing silages made from legume-grass and oats.

This study was begun with the hope that corn (where largely used as silage in wintering beef cattle) might be abandoned in erop rotation on hilly farms similar to the land on the Animal Husbandry Farm. On this farm, much danage from erosion was always observed when land was used for this crop. In the past few years, or since the corm, oats, and legume-grass (for hay) rotation has been changed to an oats, legume-grass rotation, soil erosion has been eontrolled practically 100 percent, and the productivity of the land has rapidly inereased. The same land is now producing more tonnage of silages and hays than when corn was used in the rotation.

In both 1940 and 1941, the oat silage was made by adding 40 pounds and the legume-grass silage by adding 60 pounds of molasses per ton.

Yearling heifers of Hereford and Aberdeen-Angus breeding were divided each year into two lots of ten head each (1940-41 and 1941-42) 
and wintered on growth rations. These rations were alike with the exreption that Lot I received 25 pounds of oat silage and Lot II received legume-grass silage on the basis of the same amount of dry matter. Results varied slightly from year to year. However, there was not enough variation to give an advantage to either silage, when based upon gains made by these heifers. Each silage gave good results.

Results of digestibility trials so far show that there is more digestible protein in the legume-grass-molasses silage than in the oat-molasses silage, although the latter seems to have slightly more total digestible nutrients. Neither contains as much total digestible nutrients as corn silage. With the same amount of dry matter, legume-grass-molasses silage contains twice as much digestible protein as corn silage. The dry-matter percentage content of the corn, oat-molasses, and legume-grass-molasses silages as fed was 31.8, 28.7, and 28.9, while their T. D. N. values were 21.7, 16.8, and 15.7, respectively. Their respective contents of digestible protein were 1.2, 1.6, and 2.3. The nutritive ratios of the three silages range from very wide $(1: 17.1)$ for corn silage, to $1: 9.5$ for oat-molasses silage, to narrow (1:5.8) for legume-grass-molasses silage.

As there is a scarcity of molasses now, these experiment are being continued on grass and oat silages made without molasses.

\section{Should Hay Be Stacked or Stored in the Mow?}

It is generally considered to be nore comfortable to feed hay from a mow than from a stack on cold winter days. This is without doubt correct. But, many farmers in West Virginia do not have enough haymow space for all their hay. The important question is: If the hay is put up in well-made stacks, is there serious loss in quality in one season?

During two years of experiments with two lots of 20 lambs each year, B. H. Schneider and A. H. Vantandingham have been mable to detect any difference in the condition or growth of lambs fed on stacked hay or on mow hay. The hay was fed alone one year, but in the other year it was necessary to feed a small amount of corn and linseed oil meal. The hay all came from the same field, alternating cocks going either to the stack or to the haymow. The stacks, containing two to three tons each, were carefully built.

After five months, the stacked hay was darker in color and contained less carotene (vitamine A). However, there was no difference in the gains in weight or in the condition of lambs fed twelve weeks on rations consisting entirely or largely of the hay stored in the two ways. 


\section{New Elements in Chick Feeds}

Riboflavin, a vitamin formerly known as ritamin $G$, is important for the growth of chicks. T. D. Rummels, T. B. Clark, and A. H. Tan Landingham have been trying out different feed ingredients abundant in this vitamin. Liver meal and two riboflavin concentrates which are fermentation products and known commercially as Curbay B-G and B. Y. Feeds were compared with dried skimmilk. On a riboflavin unitage basis, the liver meal and riboflavin concentrates produced growth up to 10 weeks of age comparable to that obtained from dried skimmilk. The experiment also showed that supplying the chicks with more riboflavin than is required for growth is unnecessary.

More recently, both liver meal and dried skimmilk have become scarce and rery expensive; hence the urgent need for a satisfactory substitute.

The results obtained at the Reymann Memorial Farms by T. B. Clark and R. A. Ackerman under practical conditions and methods of brooding confirmed results obtained at the University Poultry Farm, where the chicks were raised in battery brooders. Under the conditions of this experiment, the dried skimmilk gave slightly greater growth than the rations containing milk and Curbay B-G, or Curbay B-G alone, at 10 and 20 weeks of age. The Curbay B-G lot, however, had the highest feed efficiency. Therefore, for all practical purposes Curbay B-G can be used satisfactorily to provide riboflavin in starting and growing rations in the place of dried milk poducts.

\section{Vegetable Proteins in Poultry Rations}

In the 1940 Epistle I pointed out that in chick starting rations, animal protein concentrates are not superior to all vegetable protein concentrates as is commonly sapposed. Growth factors such as ritamins in the concentrates, as well as the palatability or the protein quality of the concentrates studied, may all have influenced the results. To remore the first two factors and to compare the quality of the protein in each concentrate, balance trials were conducted by A. H. TanLandingham, 'T. B. Clark, and B. H. Schneider. By so doing, the amount of protein utilized by the chicken's body was determined, giving a clue to the value of each protein concentrate.

Fish meal varies considerably in quality but it is commonly thought of as the best arailable protein concentrate for poultry. The balance trials showed, however, that the protein quality of menhaden fish meal is no better than that of soybean oilmeal. In fact, the protein of the latter ranked above that of fish meal and meat scraps and certainly 


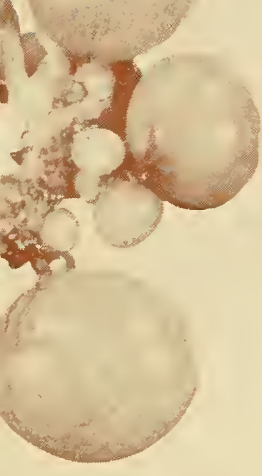
AORMAL OVARI
(UEET) COMIPARED
WITH DISEASED

OVARY AFFECTED

IVITH

IVIAN LEUKOSIS

COMPLEX

above that of corn gluten meal. In combination, the soybean oilmeal did not supplement the fish meal, but it did supplement or increase the protein utilized when fed with meat scraps or corn gluten meal.

Some animal protein may be needed in poultry rations, but only for the reason to supply some unknown growth factors and not to supplement the protein of soybean oilmeal.

It is gratifying to note that the poultry feed trade has become interested in this research and has asked our experts for particulars.

\section{Soybean Oilmeal Beneficial in Laying Ration}

The value of soybean oilmeal in the laying ration is being compared to rations containing only fish meal or meat scrap.

Control lots wele fed mashes containing fish meal alone and meat serap alone. Other lots were fed mashes containing equal parts of soybean oilmeal and fish meal and equal parts of soybean oilmeal and meat scrap.

T. D. Rumnels and E. T. Wightman report very little difference between any lots when compared on the basis of total feed consumed, percent production, or feed required per dozen egg's.

Because of the similarity of results, it would seem that soybean oilmeal may be used to replace at least half of the fish meal or meat scrap in a laying ration, and that these feeding materials may be combined in different ways, depending on the price and availability.

\section{High or Low Protein Diets for Leghorns?}

All-mash rations containing 18.5 percent and 13.5 percent of protein were nsed in studying the influence of protein level on egg produc- 
tion and mortality in White Leghorns. The chicks were grown to four weeks of age on the 18.5 percent level and then, after removing the cockerels, one-half the pullets of each hatch were continued on the same level and the other half changed to the 13.5 percent level. The pullets were housed at sexual maturity and each lot was continued on the same protein level as that on which they were grown, or one-half of each lot was continued on the same level and the other half reversed to the opposite protein level. Results are available for six lots, of 50 pullets each, for one laying year and for four lots continued for three laying years.

The percentage of egg production of the lots fed the high-protein level in either the growing or the laring period was consistently higher as compared with those fed the low-protein level in both the growing and laving periods. In two out of three rears, on in 8 out of 10 lots. the lots having the highest percentage of egg production in the first laying year had the lowest percentage of mortality that year. In four comparable lots, the mortality over a three-rear period was equalized; the high producing lots which had the lowest mortality the first laying year, had a higher rate of mortality the second and third years. T. B. Clark, T. D. Rumnels, J. H. Rietz, and C. E. Weakley, Jr., are the experimenters on this project.

\section{The Avian Leukosis Complex}

About 500 birds have been autopsied in the past year and of these, 136 cases of arian leukosis complex were diagnosed. Reproductive disorders accounted for 97 cases. Thirty of the birds showed the two diseases together.

This experinent is being conducted jointly by E. N. Moore, E. A. Marten, and C. E. Weakley, Jr., of the West Virginia Station, and Phyllis S. MeNamara of the Regional Poultry Disease Laboratory at Last Lansing, Michigan. So far, they tell me, the results fail to prove that bacterial infections are responsible for most reproductive disorders. The causes seem hidden and varied, and this piece of research may have to go on a good while before we can be assured of finding the true cause of the disease.

\section{Shall We Cross Turkeys for Better Quality?}

Several hundred crossbred birds have been compared with purebred oftspring from three parental varieties with respect to body weight, market, and feed consumed. Broad Breasted Bronze toms have been 
mated with standard Bronze hens, with Bourbon Red hens, and with Black hens.

In earlier studies we found that the intererossing of the Bronze, Bourbon Red, and Black varieties of turkeys had little or no beneficial effect on the market qualities of the offspring. As much improvement, could result from the erossing of purebred strains of each variety.

T. B. Clark, E. A. Livesay, and T. D. Rumnels report that the market qualities of the standard Bronze and Bomrbon Red varieties are improved by crossing hens of these varieties with Broad Breasted Bronze toms. At market age the crossbred toms were almost as heavy as toms of the Broad Breasted Bronze variety, while the exossbred hens were intermediate in size. The erossbreds of both sexes graded higher and had slightly broacler breasts than the purebred offspring of the standard Bronze or the Bourbon Reds at 28 weeks of age. When sold alive, the feather color of the Broad Breasted Bronze I Bourbon Red cross might be diseriminated against, but the dressed turkeys from this cross are preferable to the turkeys from the Broad Breasted Bronze $X$ Bronze cToss.

\section{TIE CIIAIIPION ON THE OPPOSITE PAGE}

Cacapon Nita by Caesar, a registered Ayrshire cow, is the new national butterfat champion for the Ayrshire breen. On March 26, 1942, Nita completed a record of 22,756 pounds of milk and 1026.7 pounds of butterfat in 365 days. The previous breed record was 956 pounds of butterfat.

Cacapon Nita was bred and cleveloped in the Reymann Memorial herd, which is located at the University Dairy Farm at Morgantown. This cow has always been a consistent producer and in addition to her national record has the following 305-day records to her credit:

At 2 years of age, 7,357 pounds of milk including 348 pounds butterfat; at 3 years of age, 9,327 pounds milk, 428 pounds butterfat; at 4 years of age, 11,284 pounds mill, 487 pounds butterfat; at 6 years of age, 17,267 pounds milk, 740 pounds butterfat.

Cacapon Nita's performance makes her the national production champion for all ages and classes in the Ayrshire breed. 


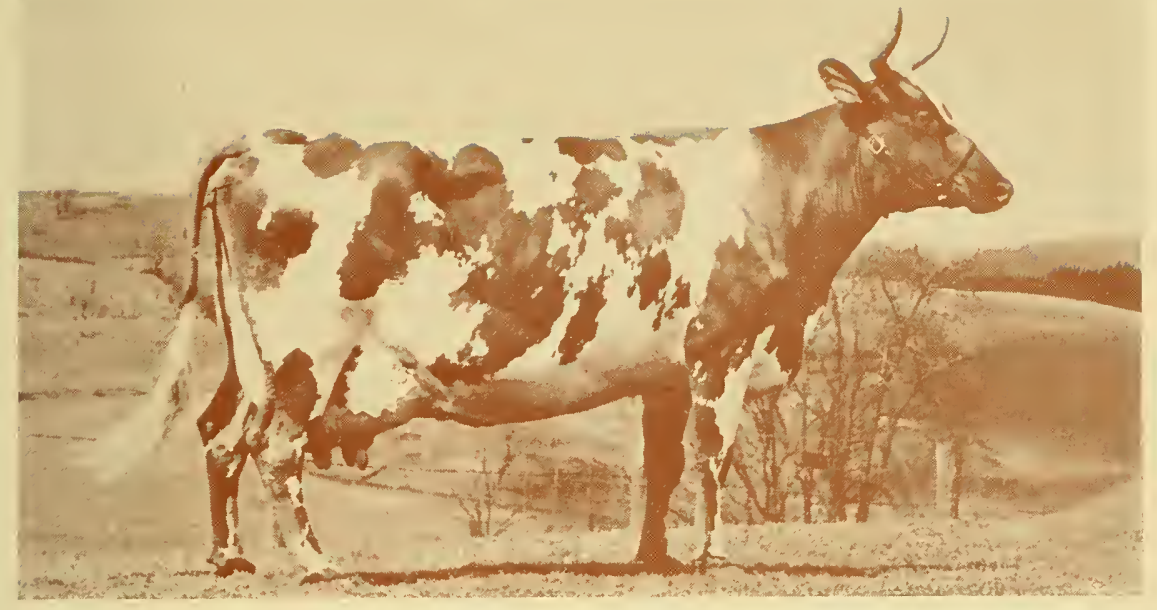

\section{Dairy Husbandry}

\section{Foster Mother of the Human Race}

It was a Middle Western agrieulturist" who, a few generations ago, coined this tribute to the dairy cow- "foster mother" of the human raee." The milk from that cow is the vehiele in which we find much that sustains life.

Caleium (lime) and phosphorus are two elements essential to the building of body tissue. Milk contains both these elements in liberal quantities and in rather eonstant proportion. This is a wise provision of nature, which sees to it that the offspring of mammals is assured of adequate nutrients in milk, even if the mother should suffer in the proeess.

Whatever comes out of the eow must first go into her in the form of feed and water. If her feed is laeking in calcium and phosphorus, she will drain these elements from her body rather than let her calves starve.

At the West Tirginia Station H. O. Henderson and A. H. VanLandingham have been studying the minerai requirements of dairy eows. They have analyzed some 600 samples of whole blood taken from 59 heifers and eows in normal states of nutrition.

Their investigation, carried out over a considerable period of years, brings out the importanee of keeping up the blood content of inorganic

* William Dempster Hoard. 
phosphorus. If there is too little phosphorus in the feed, it shows up in the blood, because the level of inorganic phosphorus goes rown. By such tests it is possible also to diagnose deficiency of vitamin $\mathrm{D}$, another' essential ingredient.

Under normal West Virgivia conditions, if cows are given adequate pasture in season and fed a legume hay and a good grain mixture in winter, there is little to be feared from lack of these elements, provided the soils in which these crops are grown have an adequate supply of lime and phosphorus.

\section{We Are Proud of This Record}

As a dairyman, would you like to own the highest-producing herd of some breed of dairy cattle in the United States? This is the accomplishment of the Reymann Memorial Hord of Ayrshire cattle, which is involved in a long-time rescarch project under the supervision of our dairy husbandmen, G. A. Bowling and D. N. Putnam.

In the past year 36 full-time producers made an average per cew of 11,555 pounds of milk and 502 pounds of butterfat, and at the time of the completion of this record it was the highest ever made by a large herd of Ayrshire cattle. This record is the result of the continued use of outstanding proved sires, the careful selection of dependable cow families, and good environmental conditions. This project has proved the wisdom of the recommended methods of herd improvement, and the results obtained should be valuable as a guide to dairy farmers in planning dairy-cattle breeding prograns.

\section{How Research Works for the Dairyman}

It may be possible for the intelligent dairyman to watch his animals so closely that he can predict, from season to season and from generation to generation, what they will produce at the pail.

It is the function of the Agricultural Experiment Station to take That burden off the farmer's back. The Station, with its staff of experts, can take a mass of details, count them, sort them, boil them down, and average the results.

That is just what we are doing with some 47,000 production records supplied by the Ayrshire Breeders' Association. G. A. Bowling and D. N. Putnam are working on these records, and alleady they have worked out a method of predicting the level of butterfat percentage that will be transmitted by young bulls of known ancestry. Other brecdimproviug facts are being obtained from these data that will be of additional value to breeders of dairy cattle. 


\section{Simplified Rations for Dairy Cattle}

Is silage necessary for satisfactory milk production if good legume. hay can be had?

II. O. Fenderson and A. H. VanLandingham report dividing 18 Holstein cows into two groups, one of them receiving only alfalfa hay for roughage, while the other group had silage in addition. It is too early for final results, although no great difference has been found in the production of the two groups. If it can be shown that good production of milk can be achieved with good alfalfa hay without sncenlent feed, and that the milk is normal in vitamin A, and not subject to off flavor's, then such a ration can be recommended without question for small herds where succulent feeds are not available.

\section{Dairy Feeds and Mastitis}

Are certain feeds or the rate of grain feeding related to mastitis?

Corn is one of the principal constituents of the concentrate ration led many dairy cows. Some dairymen are of the opinion that heavy col'n feeding may be associated with udder disturbances. In order to obtain information on this point, one group of 12 cows was fed a normal mixed ration while another group of 14 cows was fed a grain ration composed of 600 pounds of yellow corn meal, 350 pounds of corn gluten meal, 15 pounds of salt, and 10 pounds of steam bone meal. The experiment was continued for a period of two years. Both groups were fed good legume hay and silage and had access to pasture in season. Tests sbowed that animals in both groups developed mastitis, but there appeared to be no significant difference in the incidence or sererity of mastitis in the two groups.

Does the rate of grain feeding have any bearing on the development of mastitis?

Two groups of 8 lactation heifers were fed a normal mixed coneentrate ration. One group received 1 pound of grain to 3.5 pounds of riilk, whereas the other group received 8 to 10 pounds of concentrates daily regardless of the amount of milk produced.

Unfortunately these heifers were not heary producers. Nevertheless tests showed that mastitis was prevalent in both groups. In conclusion, it can be said that no appreciable increase in the incidence or severity of mastitis was observed as a result of the kind of ration or the rate of grain feeding under the conditions of these experiments.

H. O. Henderson, E. N. Noore, A. H. VanLandingham, and C. E. Weakley, Jr., are the experimenter's on this project. 


\section{What Causes Off-Flavor in Milk?}

Good milk is a palatable drink. If it were not so, mankind would not be so fond of it.

But good milk is susceptible to off flavors. and some off flavors can get so bad that the milk is not palatable.

In the process of getting the fluid to the public, milk goes through, or into, containers made of metal. That metal, if it is not properly tinned or free from scratches, has a way of imparting a metallic, or oily, or papery, or tallow taste to milk. Copper and iron are the chief offenders in this action.

Unfortmately. there are elements in the milk itself which seem to predispose the milk to the derelopment of off tastes. Ascorbic acid and glutathione are some of these ingredients. If they get in contact with some metals, something happens to their chemical make-up. They seem to oxidize. then liberate hydrogen peroxide. This in turn works on the substances surrounding the fat globules in the milk, and the result is the umpleasant oxidized flavor.

All this takes place in extremely minute amounts. If there is enough of this action, the milk becomes unsuitable for drinking purposes.

IV. C. Bromn, R. B. Dustman, and F. C. Olson are the experimenters on this project.

\section{Salt as a Cream Preservative}

Can home-produced cream be preserved so that it will be sweet when delivered to the cream station? A good bit of milk produced in West Virginia gets to the consumer via the creamery route, and the cream should be sweet when it reaches the cream station.

An experiment seeking to find a satisfactory and inexpensive way was carried out br H. K. Johnston and W. C. Brown. Each of three lots of fresh, 30 percent cream was split into two parts. one part getting 8 percent of table salt. One lot was kept at 50 degrees Fahremheit, one at 60 degrees, and one at 70 degrecs. Each lot (preserved and nonpreserved) then was divided into one-pound samples and placed in sterile quart jars. tempered to the desired storage temperature, and put in an incubator. The cream was stirred daily with a sterile rod. A pound batch of each of the preserved and non-preserved creams was remored each day, neutralized if necessary. pasteurized, and churned. The butter score was used to indicate how well cream quality was preserved.

We don't yet have complete information. but so far the indications are that salt will act as an excellent preservative for farm cream that is not liept rool enough for preservation. 


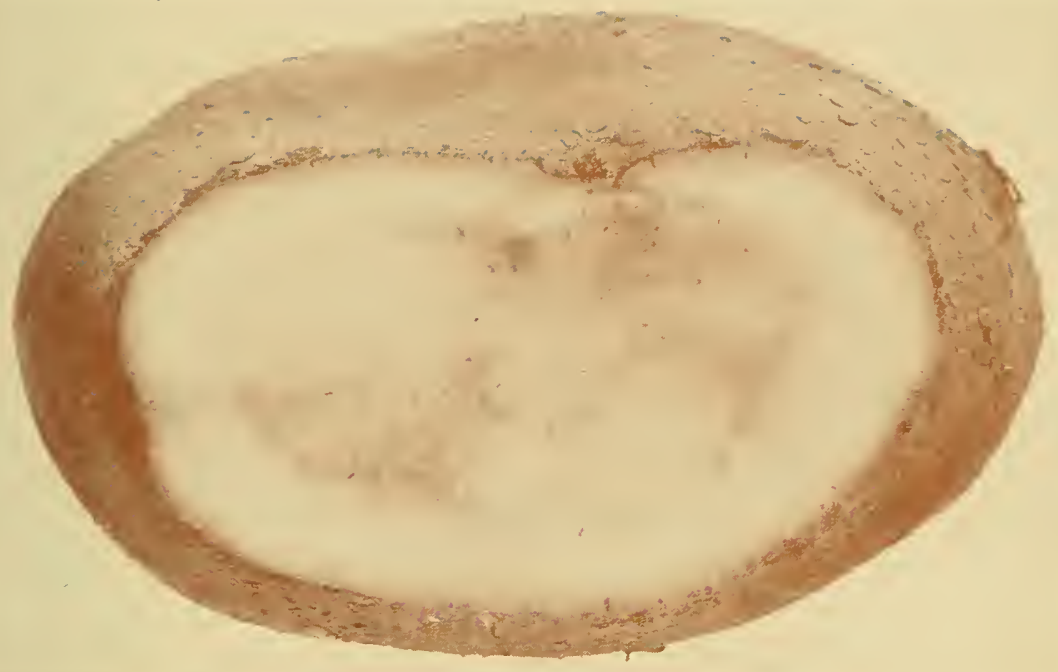

\section{Plant Disease and Insect Control}

\section{Better Fungicides Found in Substitute Search}

It so happens that many of the chemicals that we use for fighting plant diseases are also used extensively in making war on the Japs and Germans. Since military needs come first. plant pathologists are faced with the problem of finding new chemicals with which to fight the plant diseases, or stretching those we have available as far as we can. The Experiment Station anticipated this situation and for more than a year has been seeking new fungicides and methods of conserving those we have. Copper and mercury compounds and formaldehyde are the chemicals most likely to be scarce. These are used both for spraying or dusting and for seed treatment.

Since copper compounds are relatively inexpensive, we have been accustomed to use excessive amounts in our sprays to be sure of maximum control. No one knew just how much we could reduce the strength of our sprays and still get satisfactory control. An experiment on dusting potatoes carried out by Joseph Rupert (now in the Army), showed that we could reduce the strength of copper-lime dust by half and still get practically as good disease control and yield as with full strength. Further reduction, however, caused marked decrease in both disease control and yield. We now know that if there is a shortage of copper 
sulphate we ean get by with approximately half as much copper in our dusts if we use it efficiently.

Protection of regetable seeds against "damping-off" is of prime importance in ensuring good stands and avoiding seed waste. Seed treatment materials previously used have mostly been based on salts of mercury and copper, metals which must be replaced wherever possible for civilian use.

Work on a search for substitute materials in sced treatment was started in 1942 at this Station. Results to date, according to C. F. Taylor, have indicated that both thiosan and fermate (non-metallic compounds) are most promising as seed treatment materials. This work shows that they are more effective than previously used copper and mereury compounds in preventing both pre- and post-emergence dampingcff. They are non-injurious on all vegetable seeds tested with the exception of lettuce. Present indications are that these materials will prove to be new and better means of protecting seedlings, not temporary substitutes. They should aid materially in the production of the plants necessary to our food program.

As a means of further conserving copper, some fundamental studies on the factors influencing the toxicity of copper compounds were undertaken by E. A. Marten. He has found that the solubility of copper oxide is greatly increased by certain nitrogenous compounds known as amino acids. These compounds, howerer, reduce the degree of toxicity of the copper in solution. These results suggest the possibility of increasing the fungiciclal value of the copper oxide and reducing plant injury by adding some of these amino acids to the copper disinfectants. Further experiments to test this possibility are under way.

\section{Controlling Fruit Diseases with Less Copper}

As a result of many spray tests within the past four years on Montmorency cherry, fixed copper sprays have almost entirely replaced the previously used lime sulphur. But modern war demands great quantiiies of certain metals, copper being a metal in especially great demand. Recent tests by C. F. Taylor have indicated that satisfactory leaf-spot control is obtained when the schedule is modified to use lime sulphur instead of copper in the first two or three sprays, changing to copper at the last spray before harvest. This schedule will result in a saving of copper sprays on cherries by from 50 to 60 percent. Also several promising organic compounds that may substitute for copper are under test but, so far, are not ready for general use. 
On apples, tests over the past five seasons have shown that, in wellsprayed orchards, dilutions of Bordeaux mixture as high as $\mathrm{I} / 2$ to 1 to 100 are safe. These dilutions tend to produce slightly less russeting of the fruit, are adequate to prevent arsenical injury, and require relatively sinall amounts of copper. However, in orchards where bitter rot and certain other diseases are prevalent, more copper must be used.

\section{A Promising Rust-Resistant Cedar}

Until a few years ago, it was believed - and not without justification - that apples and red eedar don't mix. For many year's, in fact, cedar rust had been one of the most important faetor's holding down the production of apples in the Eastern Panhandle. This made it necessary to remove many cedars of economic value as windbreals and of considerable seenie value. There was a time when W. E. Rumsey, as an appointee of the State Department of Agriculture as well as of the Experiment Station, had to take a deal of abuse from irate owners whose red cedars he marked for the axe - in keeping with duly-passed law.

The great need was for a red cedar resistant to rust.

A project was begun in 1920 by N. J. Giddings, continued by C. R. Orton, and followed through by Anthony Berg. After studying the rust fungus from every possible angle, we found that spraying cedars was of little help in eontrolling apple rust. In the meantime we tested different strains of red cedar for resistance to the disease.

We found that strain. After fifteen years of testing under conditions of heavy rust inoenlation, it has maintained its resistance. It is now being propagated and distributed to other sections of the country for further test. Judging by the many requests reeeived for it as soon as it was annoumeed, the new rust-resistant eedar will be of no small economic value.

The production of the resistant red cedar will enable people in apple-growing regions to use the red eedar for its aesthetic value, in which respect it ranks very high. The value of this contribution is difficult to estimate in terms of money, bnt, within a few years, it will greatly exceed the cost of the projeet, and the value will continue for many years.

As an example of the scenic value of the new cedar, one of the largest arboretums of the country requested the new cedar for replacing the rust-susceptible varieties that had to be removed because of excessive rust damage to highly-prized specimens of Malus.

It is now possible to grow eedars in cemeteries and parks and 


\section{WITH TWO}

SUSCEPTIRI.E

ONES AFTER

EXPOSURE TO

RUST

around school buildings without cansing economic losses to neighboring: apple orchards.

\section{Apple Measles Not Due to Lack of Boron}

Internal bark necrosis of apple, commonly refer'ed to as "apple measles", has been under observation and study for a number of years. According to Anthony Berg and Generieve Clulo, it has been definitely established that this disease is not caused by any parasitic organism but it is perhaps due to a lack of one or more of the essential elements in the soil or to the presence of some toxic element. The addition of boron to the soil, as a corrective measure, has been widely recommended in recent years, and some people have assumed that this disease is caused by lack of boron. Tery extensive experiments conducted by this Station lave shown that the application of boron does not control internal bark necrosis. A large number of samples collected from diseased and diseaseiree trees showed on analyses that boron present in the diseased trees was no lower than that in the disease-free trees. When boron was applied to the soil of diseased trees it did not check the further derelopment of the disease. Analyses of the tissues showed that these trees had taken up far more boron than is normally present in healthy trees. Extensive experiments are now in progress to determine the exact cause of internal bark necrosis so that effective remedial measmes can be worked out.

\section{Potato Wilt of Unknown Cause}

For 10 rears or longer, West Tirginia potatoes have been subject to a puzzling disease of nuknown cause known as "bluestem". It is called bluestem because of the excessive amount of blue color in the stems of affected plants. But this is not the worst aspect of the disease. Tubers produced on diseased plants develop an internal browning at 
the stem end that is very annoying to the housewife, who often must cut out and discard a large part of the tuber. (See illustration, p. 33.)

For several years we have been trying to find out the cause of this disease. Accumulated evidence indicates that it is transmitted by insects. Recent evidence obtained by J. G. Leach and C. F. Bishop adds support to the theory that bluestem is caused by the virus of aster yellows and is transmitted by the aster leafhopper. Unlike other virus diseases affecting potatoes, this one is not transmitted through the tubers and is very difficult to study. If further experiments provide proof of this cause and disclose the method of spread of bluestem, we should be able to work out some practical method of control so that more of our potatoes will be sound and white inside.

\section{Using Yeast in Food Research}

The public is becoming more and more food-conscious. Food consciousness lays greater emphasis upon the more fundamental qualities of food; hence the growing demand not only for adequate carbohydrates, proteins, and minerals, but for adequate vitamins as well. The civilized methods of preparing food are often wasteful of vitamins; therefore it becomes necessary to determine the amount of vitamins available in different foods as well as in differently prepared foods.

When it is considered that most vitamins are present in extremely minute amounts - often one part in several billion parts of foodstuff one can appreciate the difficulty and the delicacy of the assay methods. A number of microorganisms can detect unbelievably minute amounts of vitamins and have been used by various investigators in their methods of bio-assay. However, the method is still in its infancy. I. H. Leonian and V. G. Lilly have devoted a considerable part of their energies towards developing more reliable methods, and they have made considerable advance. They have employed bacteria, yeasts, and filamentous fungi. Often two test organisms are used for the assay of one vitamin.

Another line of research consists of developing strains of yeast with larger contents of vitamin. Many yeasts are able to manufacture most of their vitamins, but they must be supplied by some other's from outside sources. Leonian and Lilly have developed strains of yeast that can synthesize all of their vitamins; these strains are therefore able to make a rich growth on foods lacking in vitamins. Since yeasts are used to enrich bread, or are eaten as the best source of natural vitamins, one (an appreciate the importance of developing yeasts capable of manufacturing and storing unusually large amounts of vitamins. 


\section{Codling-Moth Control}

The codling-moth is a pest with a past. It is the most important insect attacking the apple industry. That insect has a future, too, unless we find ways to eliminate it from the orchard or, at least, nullify its influence there.

This Experiment Station has tried almost everything to bring the codling-moth under effective control. We have found that the larvae that drop to the ground from the tree are no problem, because not enough of them survive the winter to be a menace to next year's apple crop. We know that larvae that crawl down the trunk can be reached and destroyed. We know that parasites are not numerous enough to stop the moth. We know that sanitary measures will take care of the worms that cocoon around buildings. especially in the cracks of packing-shed walls. We know, too, that a stiff spray program this season will not guarantee freedom from codling-moth next year ... Whence come these pests that plague the apple orchard?

From counts made in test orchards in the Eastem Panhandle, L. M. Peairs is now convinced that the moth hibernates in the tree tops in numbers sufficient to reestablish populations next spring, and so start the cycle all over again.

Our efforts now must be directed toward the finding of effective ways to reduce the survival in the tree tops to the point where the insect cannot do damage on a commercial scale.

* * * *

There is another mode of attack on the problem. Edwin Gould of the Experiment Station, along with G. H. Geissler and E. O. Hamstead of the federal Burean of Entomology and Plant Quarantine, is experimenting with the idea of starving the insect out of a year's food supply. Since some apple trees have "on" years and "off", years, so runs their argument, why not make some "off", year a total no-crop year by de-fruiting the orchard? The following year (an "on" year), if the orchard is isolated from neighboring sources of infestation, shonld yield a heary crop free of codling-moth damage - and without benefit of costly sprays!

In an isolated experimental orchard this attempt is being carried out. In the "off" year, a killing spray is applied during the blooming season. This technique has just been started. It shows real promise of turning the trick. If it works, the grower ean afford to skip spraying for the moth in the first season after de-fruiting. And perhaps it will then be necessary to practice de-fruiting only once in several years. 


\section{Control of Insects of Major Importance}

In our search for safe and not too costly sprays for the control of insects. numerous types of insecticides have to be tried ont. Edwin Gould, G. H. Geissler, and E. O. Hamstead have been experimenting with new forms of phenothiazine, and they report that in sever'al tests it apparently equalled or exceeded lead arsenate in effectiveness against codling moth. If the price of this chemical is ever brought in line with prices on standard insecticides, then we may have a welcome substitute for the codling-moth spray materials now in use.

"Dinitro" compounds show promise of controlling the pistol casebearer through dolmant sprays, but it appears that some injury results irom their use, and we have yet to find ways to aroid such injury to the tree.

We have discovered a large number of the Comstock mealy bug in orchards and are considering methods of control which will keep this insect from becoming an important pest.

\section{Temperature and Insect Life}

Food conservation is important at all times but especially in wartime. Our research in insect behavior has lately been directed toward finding methods of control which will protect stored foods from insect diepredations.

Our entomologists report that extremely dry conditions of the foud material and of the atmosphere are runfarorable for reproduction and even for survival of the bean weevil. The flour beetle is more tolerant but is affected to some extent. Granary weevils show less effect from dry food and atmosphere, but even they are definitely affected by lack of moisture. Corn earworms, in tests at Lakin and at Morgantown, failed 10 survive the winter in hibernation. It is impossible to predict, from local climatic data, the dates of appearance of the earworns.

As for the pests of stored grain, we recommend that farmers store their new grain, right after harrest, in a separate granary. Sanitary measures include the destruction or remoral of all remnants. trash, and the like, which may contain any living stages of the insect pests.

This action will insure minimum infestation during the period between harrest and cold weather. Thereupon the grain should be stored where it will be as dry and cool as possible through winter and spring. Such treatment can be counted on to result in minimum loss in grain stored for one season only, without any other treatment. 


\section{Nutrition}

\section{How Well Do University Students Eat?}

For the past two years, the Experiment Station has been studying the eating habits of freshman students at the University. In all, 200 men and women, living under different conditions on the campus and representative of the student body as a whole, were chosen by Miss Hazel Cameron. The effect of the students' previous diet on their nutritional condition was measured by studying their blood count, hemoglobin value, and vitamin A reserve.

Wiss Cameron reports that the consistent improvement in the blood picture in winter (and in the spring of 1940) is believed to reflect better food habits acquired from eating nutritionally well planned meals in groups where individual food prejudices tend to be forgotten. The hemoglobin of the blood, since it contains iron, reflects to some extent, at least, the amount of iron that was available in the diet, although it is affected also by other factors of a well-balanced diet.

Of the men, 40 to 60 percent expressed no food dislikes but "ate everything". The percentage was somewhat lower for women, 30 to 40 percent. Of the foods which contribute significant amounts of iron to the diet, liver was the one least well liked; approximately one-fourth of students expressed a dislike for it. Eggs were less well liked by wonen than by men; spinach and prunes disliked by less than 10 percent of students. Bread was eaten in considerable amount, especially by men, the average being 7 to 8 slices daily and for women, 5 . However, approximately twice as much white bread was eaten as was whole wheat; and since at this time bread was not enriched, little iron was contributed by this food.

While milk contributes little iron to the diet, it does furnish essential food factors which may influence the body's use of iron, and is therefore important in this study. As a whole the men drank more milk than the women, the average being more than 3 glasses daily, and for the women, slightly over 2. From 75 to 90 . percent of all men drank two or more glasses, and 50 to 80 percent of the women. The women showed greater tendency to avoid milk as a "fattening" food.

In the first year, vitamin A reserves were low or borderline in 12 percent of the men and in 5 percent of the women, perhaps a reflection. of the greater use of green vegetables by the women. In the next two years, however, there were no students below normal in vitamin A. This 
may be the result of the increasing attention to nutrition and of conscious selection of better-balanced meals. This seems to be borne out by the greater consumption of milk in the past two years, too.

\section{How Capture a Vitamin?}

What is it that makes some growing plants so nutritious to livestock? We know that for humans, fresh regetables are so beneficial because they contain an abundance of certain vitamins in addition to the necessary minerals. For the same reason, milch cows thrive on lush pastures in the spring of the year.

Naturally the idea suggests itself, Why not capture that elusive substance, lock it in foods, and store it for the lean months?

Vitamin G (riboflavin), a growth-promoting substance, is present in generous amounts in bluegrass, alfalfa, and immature oat grass. A. H. VanLandingham, C. E. Weakley, Jr., and T. B. Clark have been experimenting with ways to preserve these crops and the vitamin with them. Preliminary tests indicate that riboflavin is well preserved by artificial drying or by ensiling in 50-gallon steel drums, or in wooden tanks used as experimental silos. Silages prepared in large farm silos for cattle feeding did not contain as much riboflavin as silages prepared from immature plants in small experimental silos.

\section{Phosphorus Deficiency and Rickets}

On the type of diet used in our experiments, rickets is primarily a phosphorus deficiency, and vitamin $\mathrm{D}$ acts only through making the phosphorus of the diet more completely available.

The effect of this bone disease upon growth has been studied in rats maintained on a rickets-producing diet low in phosphorus and in vitamin D but high in calcium. Even with these deficiencies in diet, some of the rats grew for a time, but the gain in weight was less than in normal rats.

Growth in such rachitic rats follows several fairly well defined patterns, and the growth of leg bones and rertebral columns is always retarded in rickets.

The findings of these experiments upon rickets in rats, by Miss Cameron, working with G. S. Dodds of the University Medical School, is much the same as in recent work on rickets in infants, in which stunting in the growth of bones and in body weight is noted. In infants, a deficiency of phosphorus has been shown to produce stunting of growth even when it is not sufficiently severe to produce active rickets. 


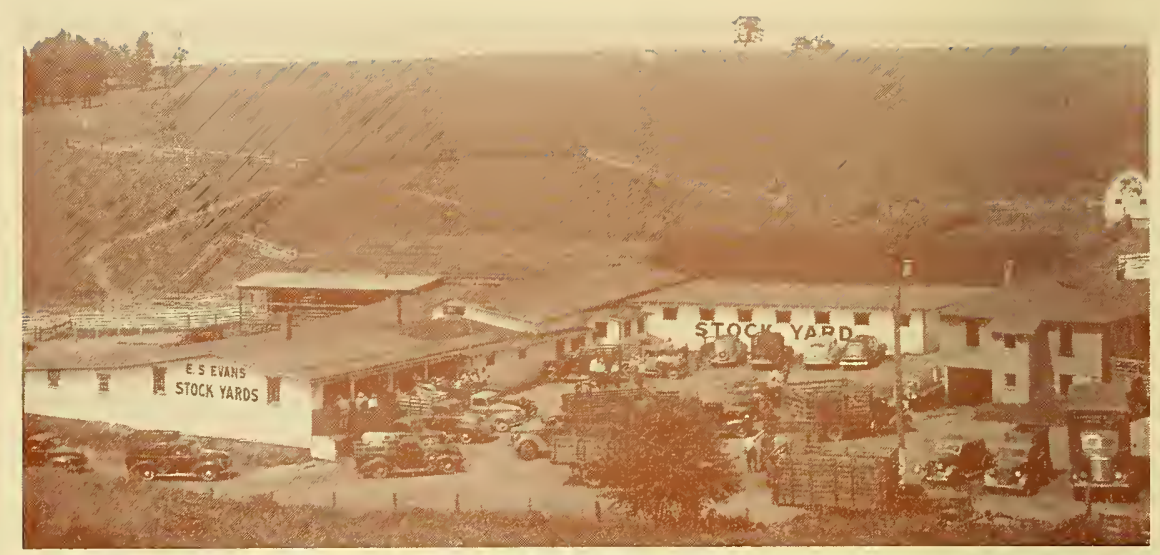

\section{Economics}

\section{What Shall We Do With Our Delinquent Lands?}

There are thousands upon thousands of acres of land in West Virginia that have gone delinquent because they became a financial burden to their owners. These lands - and they are scattered among all counties of the state - have failed to pay for their keep. The state has had to take them over.

The existence of all this delinquent land is a social liability. Everybody is the loser. It is a situation requiring the exercise of intelligent minds in search of a solution which will turn a liability into an asset.

The first job in solving this gigantic problem is to assemble all pertinent facts. Then these have to be sorted, so that we know what we are talking about.

The work the Experiment Station undertook in 1939 consisted of four major tasks:

(1) Recording, on proper forms, from county records, the ownership of each parcel of land surface in each county in the state;

(2) Checking the area as recorded in the Land Book against the records in the Deed Book:

(3) Locating, making sketches, and showing the present use of publicly owned lands; and

(4) Tabulating and analyzing all data.

From the standpoint of numbers of people employed, this is by far the largest piece of research erer attempted by the Experiment Station. The Work Projects Administration shouldered the bulk of the costs. The 
set-up included W. W. Armentrout, our Station cenomist, as project leader; E. H. Vickers, former head of the department of economies at West Virginia University, as state supervisor ; four area supervisors and lawyers; and 145 clerks working in the field - that is, in the offices of the county clerks.

The work of summarizing all the data has not been finished, and it is too early to make practical application of the facts. Incidentally, the funds for carrying out this project are exhausted, and the original purposes of the job cannot be realized until additional funds are supplied, because it will take a great deal of clerical assistance to summarize all the data. Nevertheless, we can point to these observations and results :

1. Three or four counties have used the data to correct and improve county records of land ownership.

2. Some unrecorded land has been discovered and placed on tax lists.

3. Many diserepancies between Auditor's and Sheriff's records of tax-delinquent land have been discovered.

4. The work has revealed that titles to much school property are not adequate.

And that is only a beginning. We will be able to do a lot of goor with the information when the project is completed.

\section{Conservation Reflected in Good Management}

The objective of this project is to determine the economic effects of the program administered by the Federal Soil Conservation Service on individual farms. Work on this project was begun in 1936 under the direction of E. C. Weitzell and W. W. Armentrout. Farm business records were obtained annually over a five-year period from 900 farms in six areas of the state.

Four bulletins have been published to date setting forth some of the results obtained in these studies. Bulletin 305, "Economies of Soil Conservation in West Virginia," is the summary report of the analysis of the farm business records for the period.

The work on this project is being continued under the direction of D. M. Keyes with major emphasis on ways and means of tying the Soil Conservation program in with the War effort. Detailed analytical studies are being made of data available as a basis for more definite recommendations on farm reorganization and soil and water management practices for different types of farms. Studies to date have shown that soil-conservation practices are consistent with good management. 


\section{Good Pastures, Economic Welfare Go Together}

There is a direct relationship between the quality of pastures and the economic welfare of the farming population.

That is one of the most significant findings of a piece of research carried on in the north-central pasture area of West Virginia-- the area comprising Upshur, Harrison, Lewis, and Braxton Counties. The project was carried on between 1938 and 1941 in cooperation with the Bureau of Agricultural Economics and the Agricultural Adjustment Administration of the United States Department of Agriculture.

During 1938, 1939, and 1940, Lpshur County (one of nine in the United States), served as an experimental area in which the best AAA practices were carried out in cooperation with the farmers. This experimental program -

(1) Demonstrated the value of supplying materials (lime and superphosphate) in lieu of cash paymnets.

(2) Greatly increased the amount of pasture improrement practices in that county.

(3) Had much educational value in the proper use of lime and superphosphate.

(4) Had value in improving results from seedings.

Apart from the experimental phase of the project, the study brought out the very significent fact that West Tirginia soils are characteristicalIy deficient in lime and phosphorus. There is ample experimental evidence to show that neither of these materials alone will give the results on pastures in the state that can be obtained when both are used.

Finally, the conclusion of the experimenter's is that the Agricultural Conservation Program is an effective medium through which the adoption of reasonable and desirable farm practices might be furthered.

Bulletin 304, "Farming Adjustments and Agricultural Conservation Programs in West Virginia," by F. D. Cornell. Jr., and C. Wr. Crickman, is yours for the asking.

Objective measurements of the results of pasture-improvement practices were made on approximately 25 farms in Upshur County in 1940 and 1941. We plan to publish the results of this study in the near future.

\section{Organization of Livestock Marketing Agencies}

When you consider that one-third of the state's cash farm income is derived from the sale of livestock, you understand why adequate marketing facilities are most important.

II. A. Abrahamsen has completed, in preliminary form, a study of the organization and operation of livestock marketing agencies in this 
state. He has investigated the historical development, the organization, and the operation of local slaughterhouses, local livestock dealers, cooperative livestock marketing associations. and livestock auctions.

The findings point to the need for developing adequate regulation and control of local slaughterhouse and local dealer operations. Cooperative associations would benefit from revising accounting procedure and auditing methods, taking further steps to acquaint patrons with organization set-up and operating methods, taking aggressive steps toward expanding the scope of business operations, training managers, and giving additional attention to the possibilities of furnishing a trucking service for patrons. Auctions would improve business relations if further consideration were given to such items as trading ethics. increased sanitary precautions in the handling of livestock, consolidation of operations in some competing territories, and increased patron service.

A bulletin giving a detailed report is on the way toward publication.

\section{Where Does the Dairy Business Stand?}

The physical and economic resources of the Mountain State are such that the dairy enterprise is well adapted to most sections, particularly the typical farm with a small acreage, because of the opportunity it provides to utilize comparatively large amounts of labor profitably. L. F. Miller reports that good dairymen find the production of butterfat profitable, but there is little indication that the average farmer finds butterfat production profitable enough to encourage expansion. On the other hand, a survey of farmers who have shifted from butterfat production to selling to a condensery indicates that markets of this general type may be sufficiently profitable to encourage keeping more and better cows. These farmers were not only making more money. but many were planning to make such important improvements as growing rore legume roughage, breeding higher-producing cows. and increasing the size of their herds.

\section{Joint Bull Ownership Would Cut Costs}

If we determine the influence of different factors on the cost of producing dairy products, we are in better position to reduce those costs. Both farmer and consumer will profit.

L. F. Miller has studied the records of 124 farmers in Marshall. Wetzel, Tyler, Barbour, and Upshur Counties that were producing butterfat. These records showed clearly the effect of production per cow on the cost of producing a pound of butterfat. For thirty-eight herds averaging only 147 pounds of butterfat per cow, the cost was 25 cents 
per pound compared with 18 cents for the 49 herds which averaged 200 pounds per cow. These figures cover all costs except labor, whieh amounted to 1.45 hours per pound of butterfat in the low-producing herds, eompared with 1.12 hours in the group averaging 200 pounds of butterfat per cow. The study also showed that small herds are at a disadrantage in the efficient utilization of labor and buildings, or in keeping a bull. The annual cost of keeping a bull was $\$ 5.04$ per cow for the small units, which areraged 3.6 cows per herd, compared with s1.43 for the larger herds, which areraged 8 cows. Small-herd owners inight well pool their resources and purchase one good bull for common use provided care is exereised to prevent the possible spread of disease.

\section{Stop Profit Leaks in Your Orchard}

Whether or not your commercial orchard is going to return a profit to you depends on a number of interrelated factors.

The more important of these factors have been investigated by MI. A. Abrahamsen, R. S. Marsh. C. F. Taylor, and Darid Tolkin, in cooperation with the Land Bank Division of the Farm Credit Administration. The study involved analyses of detailed cost records for 60 orchards in the Eastern Panhandle; an investigation of the disease and insect conditions in 30 orehards: a survey of apple bruising and packing; a detailed mapping of 30 orchards showing tree counts according to variety, age, soil type, and slope and erosion; and cost records for privately operated refrigerated-storage plants in that panhandle.

We have issued several reports on rarious phases of this study as mimeographed circular's of the Station. The reports have already been used by growers in checking to see how their own practices compare with the performance of other producers.

In a surver of packing methods, we find that much bruising ean be eliminated by redesigning certain packing-shed equipment and by avoiding overbulging or excess filling of boxes and baskets. No use being generous to a fault! In the survey by Marsh and Taylor, considerable variation was found in the efficient and economic use of fungicides and insecticides. To a lesser extent the same can be said about pruning.

\section{The Future of Fire Insurance Mutuals}

All farmers' mutual fire insurance companies in the state have been studied with respect to organization set-up and operating methods (Experiment Station Bulletin 302).

In summarizing this study, M. A. Abrahamsen reports the following: The future of farmers' mutual fire insurance in West Virginia 
will depend primarily upon three factors and the ability of leadershin to make adjustments in accordance with these factors. These are:

(1) Giving attention to and incorporating all possibilities for increased efficiency and better service in the performance of various operating practices. These include kinds of property insured and hazards covered, risk classification, methods of collecting money, term of policies, reinsurance and concurrent insurance, risk inspection, territory of operation, and general operating policies.

(2) Eliminating costly and unnecessary duplication in services resulting from overlapping in the territories served by mutual companies (such duplication tends to increase costs to policyholders and also may result in adequate and ineffective service).

(3) Giving further attention to means of increasing policyholder participation in company operation and to bring about increased intercompany cooperation on all problems confronting farmer's' mutual fire insurance companies.

Findings of this study have been used by secretaries and directors of some companies in checking on the effectiveness of operating practices used.

\section{The Future of Cut-Over Forest Areas}

The utilization of forest land in West Virginia is influenced by a number of physical, economic, and social problems. These are being studied in Webster and Nicholas Counties by Torkel Holsoe and L. F. Miller in cooperation with E. C. Weitzell of the Burean of Agricultural Economics, United States Department of Agriculture. In three magisterial districts, information was obtained regarding the character of the family units and sourees and rolume of income by means of a personal interview with every fourth household. The present land use and forest types were mapped for one district. Stand densities, species, and growth rates were obtained from sample plots. Data regarding land ownership, tax policy, and operating practices and attitudes of mill operators and land owners were obtained on a county-wide basis.

So far, these facts stand out: (1) In 1941, approximately 45 percent of all families in the three sample areas received total eash incomes, excluding relief, of less than $\$ 250$. (2) In general, the practices of forest operators have not been consistent with long-time forest production. (3) Present land owners indicate a desire to liquidate their resource, having no long-time interest in forest management. (4) Forests in the area are among the more productive in the state, but future employment from the woods can be expected to take care of only part of the population needing additional employment. 


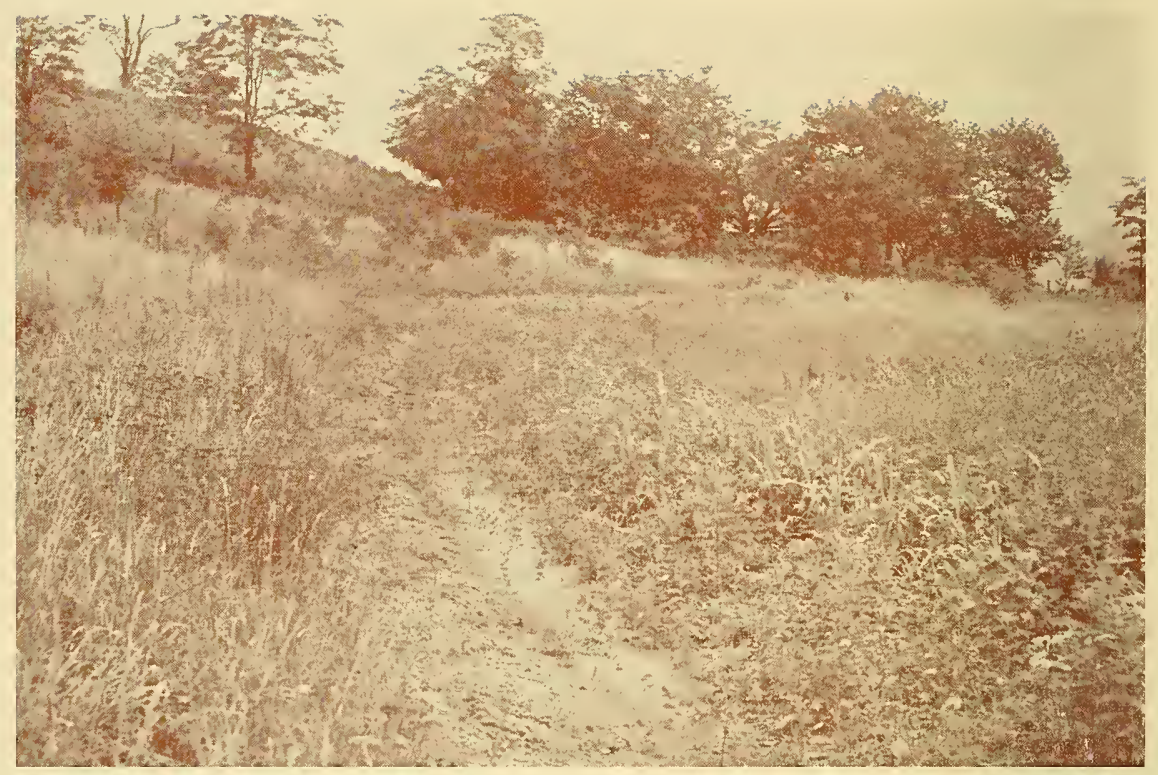

\section{Forestry}

\section{How Manage Private Woodlands Profitably?}

For long, this Experiment Station has preached a system of woodland management by which free growth would be maintained from year to year, and the timber crop harvested at regular intervals. The West Virginia Forest Products Association was organized with that as one of its aims, and the association has amply demonstrated the advantages of such management. But it has been an uphill strugghe to bring woodland owners to the point where they will continue on their: own.

W. C. Percival is the leader in this project, which has the collaboration of the Agricuttural Extension Division, the United States Forest Service, the Appalachian Forest Experiment Station, the State Conservation Commission, the Upper Monongahela Valley Association, the West Virginia Pulp and Paper Company, and the Morrison and Gross Lumber Company.

It has been found that there are at least four phases to the problem of actually bringing private woodlands under conservative management. These are: (1) education of woodland owners, (2) furnishing specific data and plans for individual tracts. (3) supervision of the woods operations for the great majority of woodland owners, and (4) provision of markets in some areas where favorable markets may not exist. 


\section{Farm Game and Soil Conservation Practices}

Nany of the standard practices of soil conservation, strip-cropping, spot-planting, etc., should be beneficial to game and wildlife. To determine more accurately the value of such practices to game, the Division of Forestry, the Agricultural Extension Division, the Soil Conservation Service, and the State Conservation Department are cooperating on a project which involves mapping of cooperating farms, making game censuses and inventories on these farms, recording of game kills and fur catches, determining the dollars and cents value of these crops, and recording trends which follow the planting of game food patches, shrub borders, and woody plantings of soil-conserving species.

Maurice Brooks, J. Fred Mc.Jurray, and R. F. Dugan have been directing this work, and have superintended the planting of some two hundred thousand trees and shrubs on cooperating farms. The work is still too new for results to be in evidence. (See game food strip, p. 48.)

\section{Black Walnut and Apple Trees Do Not Agree}

There are some classes of plant life which simply don't mix. Take black walnut. That useful and ornamental tree is bad medicine for apple trees and for some garden crops like potatoes and tomatoes.

Maurice Brooks has been making investigations of one hundred black walnut trees in 22 counties - Monongalia, Preston. Tpshur, Lewis, Harrison, Mason, Jackson, Gilmer, Calhoun, Wood, Pleasants. Ritchie, Tyler, Wetzel, Hancock, Randolph. Pocahontas, Greenbrier, Summers. Grant. Hardy, and Hampshire. The survey included classifying the regetation under and around each tree.

No important forest tree species and no native woody plants (except members of the Heath family) seem to be held back by this tree. Even in fairly dry sites the better grasses (bluegrass, timothy, redtop, orchard grass, etc.) are prevalent and make good stand under walnut, while the poorer grasses are sparse. There is every reason. I think, for encouraging the planting of black walnut in pastures and at the woody border's in this section of the United States.

In view of the widespread practice of planting walnuts on land under Soil Conservation Service management, it is important to know what woody species, and what herbaceous species, are encouraged or inhibited by walnut trees. Our present study shows that pasture improvement may be expected from such a practice, that cattle find grasses under walnut palatable, and that other important forest species will not be inhibited by the presence of walnut. Walnut and apple, or walnut and potatoes, or walnut and tomatoes, should not be brought into elose 
association, however. And there is some evidence that alfalfa does not thrive under wahnut.

\section{Fast-Growing Trees for Coal Lands}

Altogether, several million aeres of forest land in southern West Yirginia are owned by large companies, notably coal-land companies. For the most part, these companies have considered the value of the forest on their lands of small account and have allowed them to be eut down to the smallest tree capable of producing a mine prop and to be burned frequently.

Some day, the coal resources will be no more. Then the land own(rs will be wishing for stands of merchantable timber.

Lowell Besley's project with rates of growth of certain species shows that three of the four major forest types represented in the region of study, and particularly the cove-hardwoods and oak-hickory types, seem capable of responding generously to practical forestry measures, since individual tree growth is rapid. Those measures are first, adequate protection against fire, and second, simple forestry practices. Such practices include (1) the removal of defective and deformed trees of good species and trees of inferior species, as rapidly as markets, careful logging, and avoidance of too great exposure of the ground permit, and (2) the leaving of a sufficient number of thrifty trees of valuable species 10 provide for a good commercial crop in a reasonable length of time.

These measures can be applied immediately under conditions as they exist today. If the recommendations are carried out even on some of the properties concerned, they will do much to alleviate what would otherwise be a serious situation with respect to local government units after the coal has been removed and the units are dependent upon forest values for survival.

\section{Profitable Tree Forms}

Not all species of trees are a paying proposition. The same thing scems to be true of tree forms. Torkel Holsoe has been collecting a great many data in Preston County, and while not all figures have been analyzed, he is able to report a definite relationship between crown development and the rate of growth or the diameter. What's more, the butt $\log$, he finds, has twice the value of the fourth $\log$, on the basis of price per board foot.

When all results have been compiled, we hope to be in position to make eutting recommendations which will guide the forest owner in producing trees of the most valuable form in the shortest course of time. In that way the grower ean help the productivity of the woods and so inerease the return from that portion of his land. 


\section{Your Experiment Station's Needs}

In the last report (1940) of the West Virginia Agricultural Experiment Station I pointed out some of the essential requirements at this Station for an adequate program of service to West Virginia farmers. It is gratifying to report that the 1941 Legislature met in part several of these requirements through a Supplemental Budget. Personnel services and current expenses were appreciably increased. The first appropriation was made for the initial construction of a muchneeded poultry plant. This is now under construction, but an item estimated at $\$ 38,000$ is needed for the completion of this modern poultry plant involving four more buildings.

The 1941 Legislature enabled us to purchase part of the coal under the Horticulture Farm, thus preventing further removal and serious subsidence. Funds for the purchase of an additional acreage of farm land for the Animal Husbandry Department were also provided, as well as a hardening room for the creamery and some additional equipnent. In addition to the request for appropriate funds to enable the Agricultural Experiment Station to complete the new poultry plant, r'equests have been presented in the current budget for a machine shed and apple-storage plant for the University Experiment Farm at Kearneysville. This last item would mean a substantial saving to the state because of the present necessity of renting storage and haulage at distant points.

The greatest need of the Experiment Station is a new building. This may well be an addition to Oglebay Hall, which now partially houses, under very congested conditions, the College of Agriculture, Forestry, and Home Economics, including the Agricultural Extension Service. It is conceded that under War conditions it would be impractical to construct such a unit because of the scarcity of certain necessar'y strategic materials. However, if a portion of the surplus funds now available in the state treasury could be set aside for construction of this building, it could be started as soon as materials become available after the War is concluded.

The Station buildings have never been adequately maintained with respect to repairs. The insignificant budget for painting buildings, lieeping fences in repair, and many other items, should be materially increased.

Also the Station has been handicapped by insufficient funds to pay to our personnel sufficient salaries to hold then against the competition from other colleges and universities outside the state for technically 
t1ained men and women. We are constantly training young men and women for technical service and then find ourselves umable to retain them for our own service. This makes your Experiment Station a contributor to our sister states, a practice which would receive my approbation if funds were adequate to exchange the service with other institutions and states on an equal basis. Until equality of salaries of Experiment Station employees as between neighboring states is reached, West Tirginia Agriculture will be donating valuable services to other states.

\section{Staff Changes}

New appointments within our lesearch staff during the two-year period 1940-1942 include R. H. Black, assistant in animal husbandry: D. R. Browning, assistant in agronomy ; J. B. Byers, assistant in forestry; D. M. Keyes, assistant agricultural economist; H. K. Johnston, assistant in dairy husbandry; J. F. Mc.Iurray, assistant in wildlife management; O. M. Neal, assistant in horticulture; F. C. Olson, assistant chemist; and J. R. Webb, assistant in agronomy.

Promotions include M. A. Abrahamsen, associate agricultural economist; W. H. Childs, assistant horticulturist; E. A. Marten, associate bacteriologist; and A. H. VanLandingham, assoriate chemist.

During the same period the following have resigned: M. O. Akins, assistant in animal husbandry; F. P. Brasher, assistant horticulturist; D. S. Brown, assistant in horticulture: M. S. Buchanan, assistant in animal husbandry; W. H. Conkle and W. H. Duis, assistants in horticulture; H. K. Johnston; Edna D. Shaffer, assistant in agronomy; David Yolkin, assistant in agricultural economies; and F. C. Weitzell, assistant agricultural economist.

Leaves of absence for military service have been granted to Lowell Besley, associate forester ; R. H. Black; W. MI. Broadfoot, assistant in agronomy; J. B. Byers; J. F. McMurray; L. J. Manus, assistant in dairy husbandry; A. S. Margolin, photographic assistant; O. M. Neal ; and T. D. Rumnels. Also on leave is W. W. Armentrout. 


\section{PUBLICATIONS OF THE BIENNIUM 1940-1942 \\ BULLETINS AND CIRCULARS}

Bul. 296. E. A. Livesay. Finishing two-year-old steers with grass and grain. 12 pl. Oct. 1940.

Bul. 297. M. A. Abrahamsen. Cooperative purchasing of farm supplies in Trest Virginia. $76 \mathrm{pp}$. Oet. 1940.

Bul. 298. C. R. Orton. Epistle to the farm. (Report of the director, Trest Virginia Agricultural Experiment Station, Morgantorn, for the biennium 19381940) 48 pp. Dec. 1940.

Bul. 299. Proceedings of the 1940 conference on low-income farms. 45 pp. Alril 1941.

Pul. 300. L. Besley. Practical forest management for the cut-orer hardwood lands in Southern West Virginia. 64 pp. April 1941.

Isul. 301. E. C. Weitzell. Farm management for soil conservation in the Harrison area. 52 pp. May 1941. In cooperation with the Bureau of Agricultura] Economics and the Soil Conservation Service, U. S. D. A.

Bul. 302. M. A. Abrahamsen. Farmer's' mutual fire insmance companies in Trest Virginia. 14 pp. Oct. 1941.

Bul. 303. G. M. Bromning and R. H. Sudds. Physical and chemical properties of soils in the Eastern Panhandle of TTest Tirginia. $56 \mathrm{pp}$. March 1942.

Bul. 304. F. D. Cornell, Jr., and C. T. Crickman. Farming adjustments and agricultural conservation programs in Test Tirginia. 40 pp. April 1942. In cooperation with the Bureau of Agricultural Economics and the Agrieultural Adjustment Administration, U. S. D. A.

Cir. 77. J. R. Vaughn and J. G. Leach. Ring-rot disease of potatoes. 8 pp. March 1942.

\section{MIMEOGRAPHED CIRCULARS}

No. 42. F. D. Cornell, Jr., and C. IT. Crickman. Greener pastures in Upshur County, West Virginia. July 1940. In cooperation with the Bureau of Agricultural Economies and the Agrieultural Adjustment Administration, U. S. D. A.

No. 43. D. Volkin and M. A. Abrahamsen. Refrigerated-storage plants in the Eastem Panhandle of West Virginia. Dec. 1940.

No. 44. E. J. Wellhausen. Results of hybrid corn yield trials in West Virginia for 1940. February 1941.

No. 45. E. J. Wellhausen. Results of hybrid corn yield trials in Trest Virginia for 1941. Mareh 1942.

\section{WAR SERIES CIRCULARS}

Cir. WS 1. E. J. Wellhausen. Plant hybrid eorn for victory-for profit. April 1942. Cir. WS 2. F. W. Schaller and H. O. Henderson. Supplementary pastures. May 1942. Cir. WS 3. R. O. Weibel. Soybeans. May 1942.

Cir. WS 4. H. O. Henderson, E. A. Livesay, and A. H. VanLandingham. Grass silage for West Virginia. May 1942.

Cir. WS 5. I. J. Dunean and E. J. Wellhausen. Homemade sorghum syrup. Мay 1942.

Cir. WS 6. Subcommittee on Storage. Store food for the winter. June 1942.

\section{MIMEOGRAPHED WAR SERIES CIRCULARS}

M.W.S. 1. M. A. Abrahamsen and G. Heebink. Milk distribution under wartime conditions. June 1942.

M.W.S. 2. L. M. Peairs. Corn earworm control. June 1942.

M.W.S. 3. C. F. Taylor. Browu rot of store fruits. June 1942.

M.W.S. 4. R. H. Bradford. Farm labor aids. June 1942. 


\section{SCIENTIFIC PAPERS}

No. 225. R. H. Sudds. The comparatice performanee of sereral standard apple rarieties on certain stocks, principally the elones Malling I, II, and XIIT. Proc. Amer. Soc. Hort. Sei. 37: 311-31s. 1939.

No. 226. E. H. Trner. The use of sodium metaphosphate for dispersion of soils in mechanical analysis. Soil Science 4: 106-113. 1939.

No. 227. L. H. Leonian and $Y$. G. Lilly. Studies on the nutrition of fungi: IV. Factors influencing the growth of some thiamin-requiring fungi. Amer. Jour. Bot. 27, no. 1: 18-26. Jan. 1940.

No. 228. R. H. Sudds and G. E. Yerkes. The effect of Malling II and IX rootstocks on six apple rarieties. Proc. Amer. Soc. Hort. Sci. 37: 319-321. 1939.

No. 229. R. B. Dustman and I. J. Duncan. The effect of certain thiocyanate sprays on foliage and finit in apples. Plant Physiol. 15: 3 $43-3 \pm 8$ (with one colored plate). April 1940.

No. 230. G. M. Bromning. Tolume change of soils in relation to their infiltration rates. Proe. Soil Sci. Soc. of Amer. 4: 23-27. 1939.

No. 231. G. E. Terkes and R. H. Sudds. The effect of the stocks on seven rear's' growth of four apple varieties. Proc. Amer. Soc. Hort. Sei. 37: 294-297. 1939.

No. 232. L. H. Leonian and V. G. Lilly. Studies on the nutrition of fungi: T. Factors affecting zrgospore formation in Phycomyces blaliesleeanus. Amer.

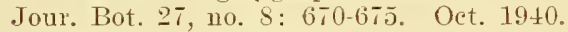

No. 233. L. M. Hill. The influence of certain cultural practicés and disease control on rield of potatoes. Amer. Potato Jour. 18, no. 5: 121-131. May 1941.

No. 234, A. Berg. A rust-resistant red cedar. Phytopath. 30, no. 10: S76-878. Oct. 1940.

No. 235. L. H. Leonian and T. G. Lilly. Studies on the mutrition of fungi: III. Auxithals sinthesized by some filamentous fungi. Plant Pliysiol. 15: 515-525. 1940.

No. 236. TV. C. Brown and L. M. Thurston. A review of oxidation in milk and milk products as related to flaror. Jour. Dairy Sci. 23, no. 7: 629-685. July 1940.

No. 237. T. G. Lilly and L. H. Leonian. The growth rate of some fungi in the presence of cocarboxylase, and the moieties of thiamin. Proe. Thest Va. Acad. Sci. 1t: 44.49 . Oct. 1940 .

No. 238. A. S. Margolin. The carbohydrate requirements of Diplodia macrospora. Proc. West Ta. Acad. Sci. 14: 56-59. Oct. ,1940.

No. 239. G. A. Bowling, D. N. Putnam, and R. H. Ross, Age as a factor influeneing breeding efficieney in a dairy herd. Jour. Dairy Sei. 23, no. 12: 11711176. Dee. 1940.

No. 240. T. Holsoe. Fertilizing planting stock on eroded soils. Jour. Forestry 39, no. 1: 69-70. Jan. 1941 .

No. 241. T. G. Lilly and L. H. Leonian. Some fretors affecting dry weight of Chlorella vilgaris. Amer. Jour. Bot. 25, no. 7 : 569-572. July 1941.

No. 243. E. Gould and G. H. Geissler. Parasites of the pistol case-bearer. Jour. Econ. Entom. 33, nо. 5: 814-\$15. Oct. 1940.

No. 244. W. C. Brown, R. B. Dustman, and C. E. Teakley, Jr. Oxidized flavor in milk: VIII. The effect of the degree of saturation of fat in the ration of the cow upon the iodine number of the butterfat and the susceptibility of milk to metal-induced oxidized flaror. Jour. Dairy Sei. 2t, no. 4: 265-275. April 1941.

No. 245. E. A. Livesay, A. H. TanLandingham, and B. H. Schneider. Con silage studies. Proe. Amer. Soc. An. Prod. 33: 126-130. 1940.

No. 246. R. H. Sudds and P. C. Marth. Wind damage to apple trees on selected rootstocks, Kearneysrille, West Tirginia, July 2S, 1940. Proc. Amer. Soc. Hort. Sei. 38: 299-30t. 1940. 
No. 247. E. P. Brasher. Growth and yield of the tomato plant when hardened with certain nutrient solutions. Proc. Amer. Soc. Hort. Sci. 38: 629-632. 1940.

No. 215. E. P. Brasher. The influence of split applications of complete fertilizer on the vield of Irish potatoes. Amer. Potato Jour. 1S, no. 3: S1-S5. March 1941.

No. 249. E. P. Brasher. A preliminary report on two plants rs. one tomato plant per stake. Proc. Amer. Soc. Hort. Sci. 39: 329-331. 1941.

No. 250. A. H. VanLandingham, C. E. Weakley, Jr., E. N. Moore, and H. O. Henderson. Mastitis: I. The relationship of the development of mastitis to changes in the chlorine, lactose, and casein number of milk. Jour. Dairy Sei. 24, no. 5: 383-398. May 1941.

No. 251. G. M. Browning and F. M. Milam. A comparison of the Briggs-MeLane and the Goldbeek-Jackson centrifuge methods for determining the moisture equivalent of soils. Soil Sei. 51: 273-278. April 1941.

No. 252. G. M. Browning and F. M. Milam. The lateral movement of water in relation to pasture contour furrows. Soil Sici. Soc. of Amer. 5: 386-359. 1940.

No. 253. G. MI. Browning and H. G. Fogle. The relation of type and amount of pasture regetation to the dispersion ratio. Proc. Soil Sci. Soc. of Amer' 5: $42-44.1940$.

No. 254. K. C. Westover. The influence of fertilizer on potato tuber shape. Amer. Potato Jour. 18, no. 6: 155-163. June 1941.

No. 255. W. H. Childs. Production, berry size, and growth of red raspberries as influenced by mulehing. Proc. Amer. Soc. Hort. Sei. 38: 405-409. 1940.

No. 256. F. W. Sehaller. The downward movement of lime and superphosphate in relation to permanent pasture fertilization. Soil Sei. Soc. of Amer. 5: 162-166. 1940 .

No. 257. R. H. Sudds and G. M. Browning. The effect of soil-management methods on certain physical and chemical properties in relation to the infiltration rates in West Virginia orchards. Proe. Amer. Soe. Hort. Sci. 39: 38-46. 1941.

No. 258. K. C. Westover. The effeet of the topping of roung tomato plants om fruit set and vield. Proc. Amer. Soc. Hort. Sei. 38: $517-522.1940$.

No. 259. W. H. Duis. Selection of the low-bush blueberry in West Virginia. Proc. Amer. Soc. Hort. Sei. 3s: 434-437. 1940.

No. 260. W. M. Broadfoot and G. M. Browning. Factors affecting the determination of sodium in plant material. Jour. Asso. Off. Agr. Chem. 2t, no. t: 916-926. Nov. 1941.

No. 261. H. W. Thurston. Jr., C. F. Taylor, A. B. Groves, and H. J. Miller. Interstate cooperative experiments on field spraying of sour cherries. Phytopath. 31, no. 11: 1047-1050. Nov. 1941.

No. 262. J. G. Leach and J. R. Mullin. The daily flight of aster leaf-hoppers as determined by a light trap. Proc. WV. Va. Aead. Sei. 15: 93-95. Feb. 1942.

No. 263. S. L. Galpin. Blister slips in West Virginia. Soil Sci. Soc. of Amer. 5: $418-420 . \quad 1940$.

No. 264. Fdwin Gould and G. H. Geissler. Hibernating codling-moth larvae. Jour. Econ. Entom. 34 (3): 445. Aug. 1941.

No. 265. G. M. Browning. The relation of field capacity to moisture equiralent in soils of West Virginia. Soil Sci. 52, no. 6: 445-450. Dec. 19-11.

No. 266. G. G. Pohlman and R. A. Nottingham. Numbers of microorganisms in relation to aggregate size. Ia. State Coll. Jour. Sci. 15 , no. $4: 447-450$. July 1941.

No. 267. W. C. Brown, A. H. VanLandingham, and C. E. Weakley, Jr. Oxidized flavor in milk: IX. The effect of the quality of hay and early stage of lactation on the carotene content of butterfat and the aseorbic acid content of the milk and their relationship to the development of metalindueed oxidized flavor. Jour. Dairy Sci. 24, no. 11: 925-935. Nov. 1941. 
No. 268. Tr. C. Brown, A. H. VanLandingham, and C. E. Weakley, Jr. Oxidized flavor in milk: $\mathrm{X}$. The effect of feeding potassium iodide supplements to dairy cows on the carotene content of the butterfat and on the ascorbic acid content of the milk and the relationship to metal-induced oxidized flavor. Jour. Dairy Sci. 24, no. 12: 1035-1039. Dec. 1941.

No. 269. A. H. VanLandingham, T. B. Clark, and B. H. Schneider. Percentage utilization and supplementary relationships of certain protein concentrates in semi-purified basal diets for growing chickens. Poult. Sci. 21, no. t: 3t6-352. July 1942.

No. 270. Edwin Gould and G. H. Geissler. Codling-moth emergence actirity studies. Jour. Econ. Ent. 34, no. 4: 576-579. August 1941.

No. 271. R. H. Sudds and D. S. Brown. The effect of peat moss on the first two seasons' growth of apple and peach trees set in 1939 in West Virginia. Proc. Amer. Soc. Hort. Sei. 40-54. 1942.

No. 272. E. N. Moore, H. O. Henderson, A. H. VanLandingham, and C. E. Weakley, Jr. Feeding as a contributory factor to the development of chronic mastitis. Amer. Jonr. Vet. Res. 3, no. 7: 154-158. April 1942.

No. 273. G. M. Bromning and F. M. Milam. Rate of application of organic matter in relation to soil aggregation. Proc. Soil Sci. Soc. Amer. 6: 96-97. 1941.

No. 274. B. H. Schneider. Direct methods of computing rations. Jour. Animal Sci. 1, no. 3: 246-255. August 1942.

No. 275. W. H. Childs. Some plant-spacing results with six strawberry varieties. Proc. Amer. Soc. Hort. Sci. 40: 357-360. 1942.

No. 276 . K. C. Testover. Further studies on the effect of topping young tomato plants on fruit set and yield. Proc. Amer. Soc. Hort. Sci. 41: 285-288. 1942.

No. 277. G. A. Bowling. The introduction of eattle into colonial North America. Jour. Dairy Sei. 25, no. 2: 129-154. Feb. 1942.

No. 278. L. H. Leonian and T. G. Lilly. Vitamin synthesis by a yeast converted from a heterotrophic to an autotrophic habit. Science 95, no. 2478: 658-659. June 26, 1942.

No. 279. L. H. Leonian and V. G. Lilly. The effect of vitamins on ten strains of Saccharomyces cerevisiae. Amer. Jour. Bot. 29, no. 6: 459-464. June 1942. 


\section{THE AGRICULTURAL EXPERIMENT STATION STAFF*}

C. E. LAWALL, M. S., E. M., LL. D., President of the University

C. R. ORTON, Ph. D., Sc. D. ................ Dean and Director JOHN C. JOHNSTON, Chief Clerk..... GERALD JENNY, M. S., Agricultural Editor

\section{AGRONOMY AND GENETICS}

G. G. Pohlman, Ph. D., Agronomist

W. M. Broadfoot, M. S., ${ }^{1}$ Asst. in Agron.

D. R. Browning, M. A.,2 Asst. in Agron.

J. L. Cartledge, Ph. D., Asst. Gen.

S. L. Galpin, Ph. D., Hydrologist

T. C. McIlvaine, Ph. D., ${ }^{3}$ Assoc. Agron.

F. W. Schaller, M. S., Asst. in Agron.

E. H. Tyner, Ph. D., Asst. Agron.

J. R. Webb, B. S., Asst. in Agron.

R. O. Weibel, M. S., Asst, in Agron.

E. J. Wellhausen, Ph. D., Assoc. Gen.

ANIMAL HUSBANDRY

E. A. Livesay, D. Sc., An. Husbandman

U. G. Bee, B. S., Asst. in An Husb.

R. H. Black, M. S., Asst. in An. Husb.

T. B. Clark, M. S., Asst. Poult. Husb.

E. N. Moore, D. V. M., Asst.

An. Pathologist

J. H. Rietz, D. V. M., An. Path.

T. D. Runnels, M. S., ${ }^{1}$ Asst. in Poult. Husb.

B. H. Schneider, Ph. D., Assoc. An. Husb.

E. T. Wightman, M. S., Asst. Poult. Husb.

C. V. Wilson, M. S., Assoc. An. Husb.

\section{CHEMISTRY}

P. B. Dustman, Ph. D., Agr. Chem.

V. B. Fish, B. S., Asst. Chem.

A. H. VanLandingham, Ph. D., Assoc. Chem.

C. E. Weakley, Jr., M. A. Assoc. Chem.

DAIRY HUSBANDRY

H. O. Henderson, Ph. D., Dairy Husbandman

R. A. Ackerman, M. S., ${ }^{4}$ Asst. Dairy Husb.

G. A. Bowling, M. S., Assoc. Dairy Husb.

W. C. Brown, Ph. D.. Asst. Dairy Husb.

S. A. Lear, Ph. D., Asst.

in Dairy Husb.

L. J. Manus, M. S.. ${ }^{3}$ Asst. in Dairy Husb.

D. N. Putman, M. S., Asst. in Dairy Husb.

ECONOMICS (AGR.)

W. W. Armentrout, Ph. D., 5 Agricultural Economist
M. A. Abrahamsen, Ph. D., Assoc. Agr. Econ.

R. H. Bradford, M. A., Assoc. Rural Sociol.

F. D. Cornell, Jr., Ph. D., Assoc. Agr. Econ.

D. M. Keyes, M. S., Asst. Agr. Econ.

L. F. Miller, Ph. D., Asst. Agr. Econ,

\section{ENTOMOLOGY}

L. M. Peairs, Ph. D., Entomologist

Edwin Gould, B. S., ${ }^{6}$ Assoc. Entomol.

\section{FORESTRY}

W. C. Percival, Ph. D., Forester

Lowell Besley, M. F., ${ }^{1}$ Assoc. For.

M. G. Brooks, M. S., Assoc. For.

J. B. Byers. B. S., ' Asst, in For.

R. F. Dugan, M. F., Asst. in Wildlife Mgt.

H. D. Erickson, Ph. D., Asst. For.

Torkel Holsoe, M. F., I' Asst. For.

J. F. MeMurray, B. ٌ่., ${ }^{1}$ Asst. in Wildlife Mgt.

HORTICULTURE

R. S. Marsh, M. A., Horticulturist

W. H. Childs, Ph. D., Asst. Hort.

W. H. Conkle, M. S., Asst. in Hort.

A. P. Dye, M. S., Asst. Hort.

O. M. Neal, Jr., B. S. ${ }^{1}$ Asst. in Hort.

R. H. Sudds, Ph. D. Assoc. Hort.

K. C. Westover, Ph. D., Assoc. Hort.

PLANT PATHOLOGY AND BACTERIOLOGY

J. G. Leach, Ph. D., Plant Pathologist

Anthony Berg, M. S., Assoc, Plant Path.

C. F. Bishop, M. S., Asst. in Plant Path.

Genevieve B. Clulo. M. A., Asst. Plant Path.

L. II. Leonian, Ph. D., Mycologist

V. G. Lilly, Ph. D., Asst. Physiol.

E. A. Marten, Ph. D., Assoc. Bact

C. F. Taylor, Ph. D., Asst. Plant Path.

MISCELLANEOUS

Hazel C. Cameron, M. A., Res. Assoc. in Nutrition

A. S. Margolin, Ph. D., ${ }^{1}$ Photog. Asst. W. i. Nelson, A. R. P. S., Photog.

* As of Feb. 1, 1943.

1 On leave for military service.

2 In cooperation with the United States Department of Agriculture.

${ }^{3}$ In charge of the Lakin Experiment Farm.

4 In charge of the Reymann Memorial Farms, Wardensville, West Va.

5 On leave of absence.

${ }^{6}$ In charge of the University Experiment Farm, Kearneysville, West Ta. 


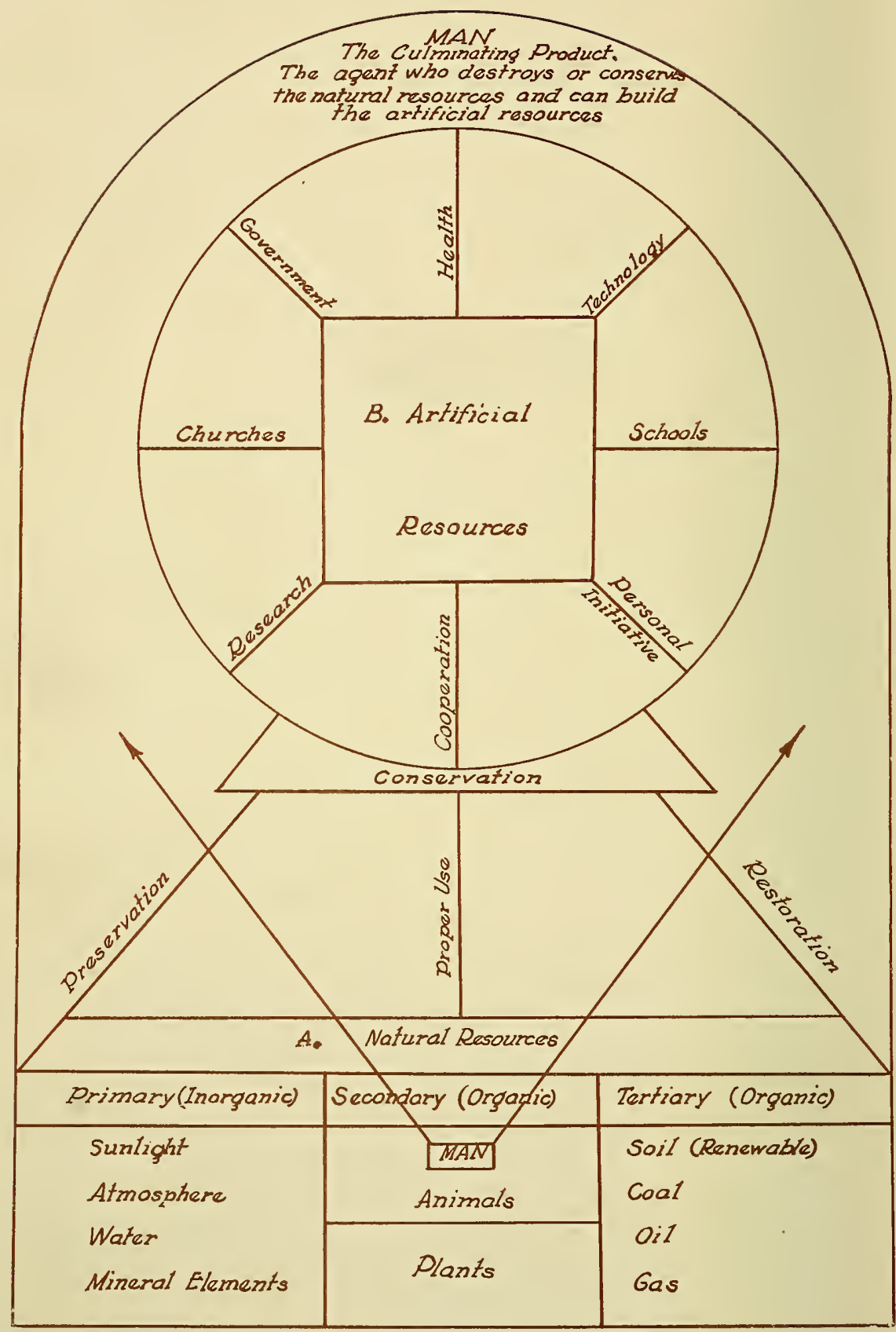

Resources + People + Planning $=$ Wealth 

. 